\title{
Visual Function in Mice with Photoreceptor Degeneration and Transgenic Expression of Channelrhodopsin 2 in Ganglion Cells
}

\author{
Senthil Thyagarajan, ${ }^{1}$ Michiel van Wyk, ${ }^{1}$ Konrad Lehmann, ${ }^{2}$ Siegrid Löwel, ${ }^{2}$ Guoping Feng, ${ }^{3}$ and Heinz Wässle ${ }^{1}$ \\ ${ }^{1}$ Department of Neuroanatomy, Max-Planck-Institute for Brain Research, D-60528 Frankfurt/Main, Germany, ${ }^{2}$ Institut für Allgemeine Zoologie und \\ Tierphysiologie, Friedrich-Schiller-Universität Jena, D-07743 Jena, Germany, and ${ }^{3}$ Department of Neurobiology, Duke University Medical Center, Durham, \\ North Carolina 27710
}

\begin{abstract}
The progression of rod and cone degeneration in retinally degenerate (rd) mice ultimately results in a complete loss of photoreceptors and blindness. The inner retinal neurons survive and several recent studies using genetically targeted, light activated channels have made these neurons intrinsically light sensitive. We crossbred a transgenic mouse line expressing channelrhodopsin2(ChR2) under the control of the Thy 1 promoter with the $P d e 6 b^{r d 1}$ mouse, a model for retinal degeneration $(r d 1 / r d 1)$. Approximately $30-40 \%$ of the ganglion cells of the offspring expressed ChR2. Extracellular recordings from ChR2-expressing ganglion cells in degenerated retinas revealed their intrinsic light sensitivity which was $\sim 7 \log \mathrm{U}$ less sensitive than the scotopic threshold and $\sim 2 \log \mathrm{U}$ less sensitive than photopic responses of normal mice. All ChR2-expressing ganglion cells were excited at light ON. The visual performance of $r d 1 / r d 1 \mathrm{mice}$ and ChR2 $r d 1 / r d 1$ mice was compared. Behavioral tests showed that both mouse strains had a pupil light reflex and they were able to discriminate light fields from dark fields in the visual water task. Cortical activity maps were recorded with optical imaging. The ChR2rd1/rd $1 \mathrm{mice}$ did not show a better visual performance than $r d 1 / r d 1$ mice. In both strains the residual vision was correlated with the density of cones surviving in the peripheral retina. The expression of ChR2 under the control of the Thy1 promoter in retinal ganglion cells does not rescue vision.
\end{abstract}

\section{Introduction}

Inherited degenerations of rods and cones that result in blindness affect 1 in 3000 humans worldwide. Mice carrying the rd 1 retinal degeneration mutation $(r d 1 / r d 1)$ lose nearly all of their photoreceptors (Carter-Dawson et al., 1978). They became the preferred model system for studies of retinal degenerations and for attempts to rescue the photoreceptors (Punzo et al., 2009). The mutation affects the rod phosphodiesterase (PDE), which is involved in the visual transduction cascade (Bowes et al., 1990; Farber et al., 1994). Inner retinal neurons also react to the photoreceptor death and morphological and functional abnormalities occur (Strettoi et al., 2002, 2003; Jones et al., 2003; Marc et al., 2003 , 2007). However, many inner retinal neurons and synaptic circuits survive after photoreceptor degenerations (Claes et al., 2004; Mazzoni et al., 2008).

Several recent studies was aimed at making these surviving inner retinal neurons intrinsically photosensitive and thereby restore visual functions after photoreceptor degeneration: Bi et al. (2006) injected adeno-associated viral vectors (AAV) into the

Received Sept. 8, 2009; revised May 13, 2010; accepted May 13, 2010

We thank Anne-Kathrin Pilz, Brigitte Sinke, and Elke Woker for technical assistance and excellent animal care. We are grateful to Irmgard Odenthal for typing the manuscript.

Correspondence should be addressed to Heinz Wässle, Max-Planck-Institut für Hirnforschung, Deutschordenstrasse 46, D-60528 Frankfurt/Main, Germany. E-mail: Waessle@mpih-frankfurt.mpg.de.

DOI:10.1523/JNEUROSCI.4417-09.2010

Copyright $\odot 2010$ the authors $\quad 0270-6474 / 10 / 308745-14 \$ 15.00 / 0$ vitreous and transfected inner retinal neurons, which subsequently showed a long-term expression of the microbial-type rhodopsin, channelrhodopsin-2 (ChR2) (Nagel et al., 2003; Boyden et al., 2005). Ganglion cells expressing ChR2 showed intrinsic light sensitivity (Bi et al., 2006). A comparable experiment was performed by Tomita et al. $(2007,2010)$ in blind rats (RCS, $r d y / r d y$ ). Visual-evoked potentials could be recorded in the cortex of blind mice and rats after AAV transfection of retinal ganglion cells with ChR2. Lagali et al. (2008) targeted ChR2 to retinal ON bipolar cells in $r d 1 / r d 1$ mice and could elicit stable light responses in ganglion cells. In behavioral studies $r d 1 / r d 1$ mice expressing ChR2 in ON bipolar cells showed visual responses. Lin et al. (2008) used AAV injection into the vitreous of $r d 1 / r d 1$ mice to ectopically express mouse melanopsin (Berson et al., 2002; Hattar et al., 2002), and light responses could be recorded from $10 \%$ of the ganglion cells. In behavioral studies visual responses were observed in treated $r d 1 / r d 1$ mice. Zhang et al. (2009) expressed ChR2 and halorhodopsin (Lanyi, 1986; Zhang et al., 2007) in retinal ganglion cells and observed ON, OFF and ON-OFF light responses.

We made use of transgenic mice that express a ChR2-YFP (yellow fluorescent protein) fusion protein in the CNS (Arenkiel et al., 2007). The mice were crossed into an $r d 1 / r d 1$ background and the expression of ChR2-YFP in the retina was studied. Approximately $30 \%$ of the ganglion cells expressed ChR2-YFP. Ganglion cell light responses of wild-type mice and ChR2 $r d 1 / r d 1$ mice were compared. The time course of degeneration of cones in 
$r d 1 / r d 1$ mice was monitored. Central visual responses were studied by optical imaging of intrinsic signals in the visual cortex. Finally, the visual performance of the transgenic mice was tested in a two choice visual discrimination task in the lower photopic range and at high light intensities $\left(>1 \cdot 10^{15}\right.$ photons $\left./ \mathrm{cm}^{2} / \mathrm{s}\right)$.

\section{Materials and Methods}

Wild-type mice (C57BL/6J) and the following transgenic mouse lines were used: Arenkiel et al. (2007) generated transgenic mouse lines expressing ChR2-YFP under the control of the Thyl promoter. Three of the mouse lines were tested and expressed ChR2-YFP in the retina (supplemental Fig. 1, available at www.jneurosci.org as supplemental material). Line 9 was used in the present study. The retinal degeneration mouse line $\mathrm{C}_{3} \mathrm{H} / \mathrm{HeJ}$ was purchased from Jackson Laboratories (stock number: 000659). It is homozygous for the retinal degeneration allele Pde6b $b^{\text {rd } 1}$ (rod-specific phosphodiesterase, Bowes et al., 1990). To generate mice expressing ChR2-YFP and showing degeneration of photoreceptors, we crossbred $\mathrm{C}_{3} \mathrm{H} / \mathrm{HeJ}$ mice with the transgenic mouse line Thy1 ChR2-YFP to produce the first generation transgenic line that was heterozygous for the photoreceptor degeneration and expressed ChR2-YFP. This line was backcrossed with the parent $\mathrm{C}_{3} \mathrm{H} / \mathrm{HeJ}$ transgenic line to produce the transgenic model Thy1-ChR2-YFP $r d 1 / r d 1$ which is homozygous for the mutant $P d e 6 b^{r d 1}$ gene and expresses ChR2-YFP. The line was identified from the heterozygous and wild-type animals by PCR genotyping. For the rest of this study we apply the following nomenclature: Pde6b $b^{r d 1}$ retinal degeneration mice will be named $r d 1 / r d 1$ mice, Thy1-ChR2-YFP $r d 1 / r d 1$ will be named ChR2 $r d 1 / r d 1$ mice.

All procedures were approved by the local animal care committee and were in accordance with the law of animal experimentation issued by the German Government (Tierschutzgesetz).

\section{Tissue preparation, histology, and antibodies}

The mice were deeply anesthetized with isoflurane and killed by cervical dislocation. The eyes were removed and dissected, and the posterior eye cup containing the retina was immediately immersed in $4 \%(\mathrm{w} / \mathrm{v})$ paraformaldehyde in $0.1 \mathrm{~m}$ phosphate buffer (PB) $\mathrm{pH} 7.4$, for 15-30 min. After fixation, the retina was dissected from the eye cup. For frozen sections it was cryoprotected in graded sucrose solutions (10,20 and $30 \%$, respectively) and cryostat sections were cut at $14 \mu \mathrm{m}$, mounted and stored at $-20^{\circ} \mathrm{C}$. For retinal whole mounts, the tissue was cryoprotected and frozen and thawed several times. Whole mounts were processed free-floating.

The yellow fluorescent protein (YFP) is already visible without immunostaining because of its green/yellow fluorescence (see Fig. $1 \mathrm{~B}$ ). However, by applying antibodies against the green fluorescent protein (GFP) the fluorescence signal was enhanced (1:2000 rabbit anti-GFP, Invitrogen; and 1:500 mouse anti-GFP, Millipore Bioscience Research Reagents). Cholinergic amacrine cells were immunostained with a goat antibody against choline acetyltransferase (ChAT, 1:2000, Millipore Bioscience Research Reagents). The following antibodies against cone opsins were used: rabbit polyclonal antibodies against S-opsin (1:5000) and M-opsin (1:1000) kindly provided by Dr. J. Nathans (John Hopkins University, Baltimore, MD), and goat anti S-opsin (1:1000) from Santa Cruz Biotechnology. Antibodies were diluted in PBS, pH 7.4, containing $0.5-1 \%$ Triton X-100 and $0.05 \%$ sodium azide with either 3\% normal donkey serum or 5\% Chemiblocker (Millipore Bioscience Research Reagents). Immunocytochemical labeling was performed using the indirect fluorescence method. Cryostat sections were incubated overnight in the primary antibodies, followed by a $1 \mathrm{~h}$ incubation in the secondary antibodies, which were conjugated to either Alexa TM 488 (green fluorescence, Invitrogen), Cy3 (red fluorescence, Dianova) or Cy5 (dark red fluorescence). In double labeling experiments, sections were incubated in a mixture of primary antibodies, followed by a mixture of secondary antibodies. Whole mounts were incubated for $2 \mathrm{~d}$ in the primary and for $2 \mathrm{~h}$ in the secondary antibody solution. Cresyl violet staining of whole mounts was performed as described in detail previously (Wässle et al., 1975).

\section{Light microscopy}

Fluorescent specimens were viewed with a Zeiss Axioplan 2 microscope. Black-and-white images were taken by using a cooled CCD-camera (Zeiss, AxioCam Mrm). By using the Zeiss AxioVision 4.2 software images taken with the different fluorescence filters were pseudocolored and superimposed. The microscope was equipped with the Zeiss Apotome oscillating grating in the epifluorescence beam which resulted in a significant reduction of out-of-focus straylight. Images were taken with a PlanNeofluar 40x/0.75 objective as stacks of up to 30 optical sections. Density measurements of ganglion cells and cones were made by collapsing selected parts of the stacks into a single plane.

Low-power micrographs of retinal whole mounts were taken with a Zeiss Lumar V.12 microscope equipped with epifluorescence and a cooled CCD camera (see Fig. 4C). From low-power micrographs the distribution of residual cones could be studied and from selected fields, high-power micrographs were taken on the Axioplan 2 microscope and the number of cones counted (field size $440 \times 320 \mu \mathrm{m}$; see Fig. 9C).

\section{Extracellular recordings}

The methods for recording of the visually evoked responses in retinal ganglion cells have been described in detail previously (Taylor and Vaney, 2002, van Wyk et al., 2006; van Wyk et al., 2009). Mice were dark-adapted for $1 \mathrm{~h}$, anesthetized with isoflurane (CuraMED Pharma, Karlsruhe, Germany) and decapitated. The eyes were enucleated under dim red illumination and the retinas removed. A piece of central retina was placed photoreceptor-side down in a recording chamber and weighed down with a platinum harp. The recording chamber was perfused with Ames medium at $34-36^{\circ} \mathrm{C}$ (Sigma; $\mathrm{pH} 7.4$ ). Ganglion cell somas were targeted for recording using infrared differential-interference-contrast optics.

Extracellular electrodes were pulled from borosilicate glass to a final resistance of 5-8 M $\Omega$. The extracellular electrodes were filled with Ames medium while the patch electrodes contained the following: $125 \mathrm{~mm}$ K-gluconate, $1 \mathrm{~mm} \mathrm{CaCl}_{2}$, 4 mм Na-ATP, 0.4 mм Na-GTP, 10 mм EGTA, $4.6 \mathrm{mM} \mathrm{MgSO}_{4}$ and $10 \mathrm{~mm} \mathrm{Na-HEPES}$. Ganglion cells were labeled by adding Lucifer yellow (LY, $2 \mathrm{~mm}$ ) or Alexa Fluor 568 hydrazide ( $2 \mathrm{~mm}$ ) to the intracellular solution (see Fig. 5; supplemental Fig. 2, available at www.jneurosci.org as supplemental material).

\section{Light stimulation}

Dark-adapted, wild-type retina. Light stimuli for measuring darkadapted responses were white spots of $300 \mu \mathrm{m}$ diameter generated on a computer monitor with a refresh rate of $85 \mathrm{~Hz}$. The spot size of $300 \mu \mathrm{m}$ corresponds to the dendritic tree of A-type ganglion cells. The stimuli were projected via an infrared polarizing beam splitter cube (PTW 25, Bernhard Halle, Berlin, Germany) through the microscope condenser and focused onto the photoreceptor outer segments. No background illumination was applied in experiments measuring the scotopic threshold of ganglion cells in wild-type mice.

Light-adapted, wild-type retina. Light stimuli for measuring photopic responses of ganglion cells in wild-type mice were white spots generated by a video projector (Philips, Multimedia Projector LC5141, refresh rate $85 \mathrm{~Hz}$ ). Stimuli were projected, as described above onto the retina. A light spot $\left(I_{\max }\right)$ of $120 \mu \mathrm{m}$ diameter was projected onto a steady background $\operatorname{spot}\left(I_{\min }\right)$ of the same size. This spot diameter corresponds in the mouse eye to a visual angle of $4^{\circ}$. The modulation transfer function of the mouse visual system, measured by a behavioral test, peaks at 0.21 cycle/degree (Prusky and Douglas, 2004). This channel with the highest contrast sensitivity represents a receptive field center size of $4.8^{\circ}$, which would be efficiently stimulated by the chosen light spot of $4^{\circ}$. To avoid bleaching of a larger retinal area an adapting spot of the same size was chosen. The contrast of the light stimuli $\left(I_{\max }-I_{\min } / I_{\max }+I_{\min }\right)$ was kept constant at 0.95 while both $I_{\max }$ and $I_{\min }$ were increased. The lowest background was $I_{\min }=5 \cdot 10^{10}$ photons $/ \mathrm{cm}^{2} / \mathrm{s}$. The stimulus intensities for measuring the ganglion cell light responses in wild-type retinas were comparable to the light stimuli applied in the behavioral experiments described later.

Light stimulation of ganglion cells in ChR2rd1/rd1 mice. Only the blue gun of the video projector was used to stimulate the ChR2 YFPexpressing ganglion cells of ChR2 $r d 1 / r d 1$ mice. The same stimulation 


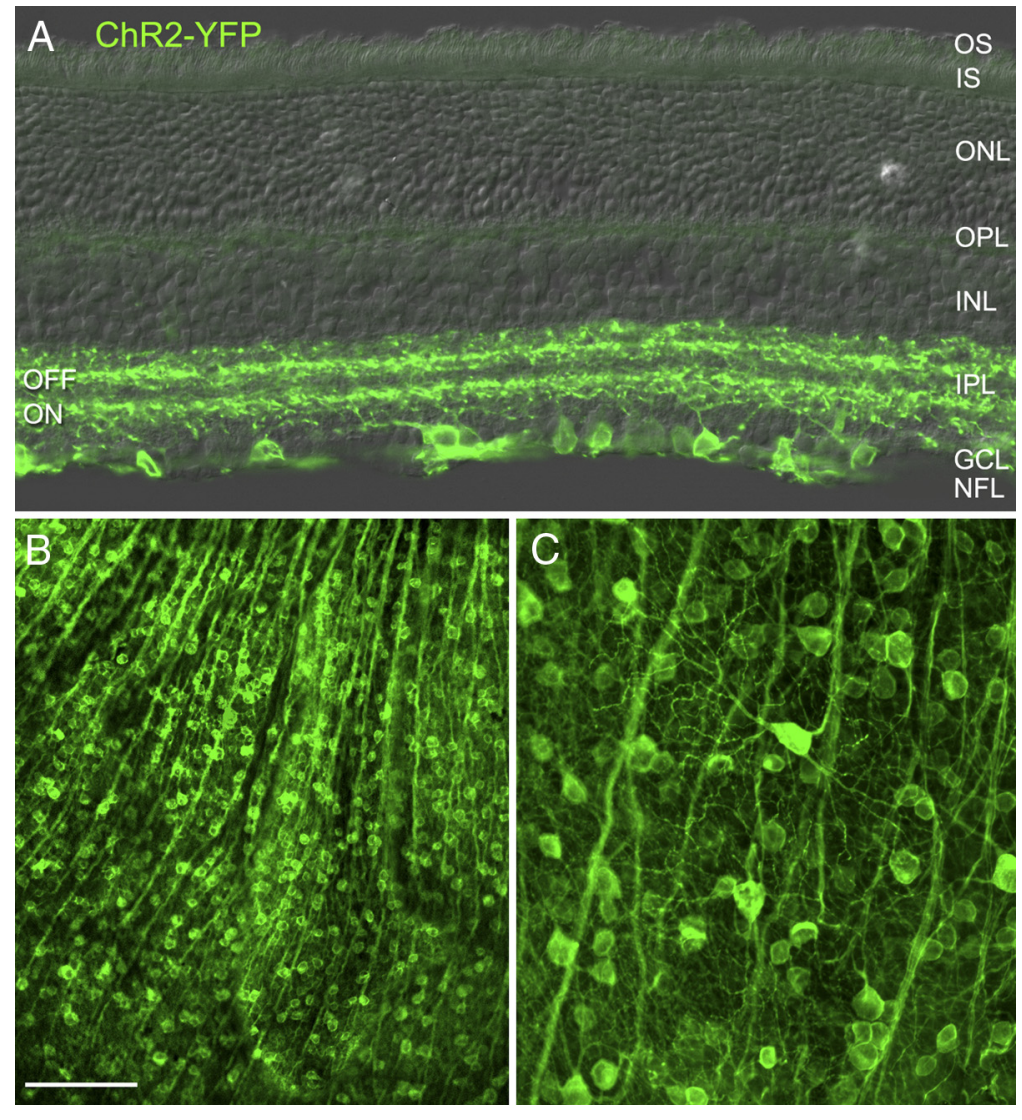

Figure 1. Expression of ChR2-YFP in the mouse retina. $\boldsymbol{A}$, Vertical section through the mouse retina. The retinal layers are visible in this Nomarski micrograph. ChR2-YFP immunofluorescence (green) is expressed in ganglion cells and their dendrites in both the OFF- and ON-sublayers of the IPL. $\boldsymbol{B}$, Endogenous fluorescence of ChR2-YFP in a retinal whole mount. Ganglion cell bodies and axons are labeled. $C$, ChR2-YFP immunofluorescence in a retinal whole mount. Ganglion cells of different cell body sizes and dendritic morphologies are apparent. OPL, outer plexiform layer. Scale bar (in $\boldsymbol{B}$ ): $\boldsymbol{A}, \boldsymbol{C}, 50 \mu \mathrm{m} ; \boldsymbol{B}, 150 \mu \mathrm{m}$.

protocol was applied as for the photopic light stimuli. The lowest background illumination was $I_{\min }=2 \cdot 10^{12}$ photons $/ \mathrm{cm}^{2} / \mathrm{s}$. The intensity of the light stimuli falling onto the retina was adjusted by neutral density filters and measured by a photometer (ILT1400, detector SEL 0.33, International Light Technologies). The Philips LC5141 multimedia projector was powered by a $150 \mathrm{~W}$ UHP lamp (Derra et al., 2005). The emitted light was filtered by a spinning filter wheel of red, green and blue sectors, and projected by a Texas Instrument DLP chip. The blue channel was used to stimulate the ChR2 YFP-expressing ganglion cells. Its spectral composition was very well matched to the spectral sensitivity curve of ChR2 (Nagel et al., 2003). The peak emission was at $460 \mathrm{~nm}$, the lower cutoff was $380 \mathrm{~nm}$ and the upper cutoff was $530 \mathrm{~nm}$. For the stimulation of the photopic cone responses in wild-type retinas, all three channels of the projector were used (RGB white), and the peak emission was at $560 \mathrm{~nm}$.

The detector of the light meter was a broad band silicon detector $(200-1100 \mathrm{~nm})$. Its spectral sensitivity at the peak of the ChR2 sensitivity $(460 \mathrm{~nm})$ was $12 \%$ lower than at the rod peak $(498 \mathrm{~nm}), 15 \%$ lower than at the M-cone peak $(510 \mathrm{~nm})$ and $34 \%$ higher than at the S-cone peak $(355 \mathrm{~nm})$. These relative differences were neglected when measuring the light intensities (photons $/ \mathrm{cm}^{2} / \mathrm{s}$ ).

\section{Visual optomotor system}

Visual acuity was assessed using the recently developed virtual-reality optomotor system (Prusky et al., 2004). Briefly, freely moving animals are exposed to moving sine wave gratings of various spatial frequencies and contrasts and will reflexively track the gratings by head movements as long as they can see the gratings. Luminances of white and black stripes were $152 \mathrm{~cd} / \mathrm{m}^{2}$ and $0.2 \mathrm{~cd} / \mathrm{m}^{2}$, respectively. None of the $\mathrm{rd} 1 / \mathrm{rdl}$ mice and ChR2rd1/rd1 mice passed this test (Schmucker et al., 2005).
Visual water task

As a second method to assess visual acuity in mice, we used the so-called visual water task (VWT), a visual discrimination task that is based on reinforcement learning (Prusky et al., 2000, 2004; Prusky and Douglas, 2004). For this task, animals were initially trained to distinguish a low spatial frequency vertical grating (0.086 cycle/degree) from equiluminant gray. The apparatus consists of a trapezoidal-shaped pool with two monitors placed side by side at one end. A midline divider is extended from the wide end into the pool, creating a maze with a stem and two arms. The length of the divider sets the choice point and effective spatial frequency. An escape platform that is invisible to the animals is placed below the monitor on which the grating is projected. The position of the grating and the platform is alternated in a pseudorandom sequence over the training and test trials. None of the $r d 1 / r d 1$ mice and of the ChR $r d 1 / r d 1$ mice passed this test. Therefore, we simplified the VWT and the animals were trained to discriminate a bright field (97 $\left.\mathrm{cd} / \mathrm{m}^{2}\right)$ from a dark field $\left(\sim 0.5 \mathrm{~cd} / \mathrm{m}^{2}\right)$ (see Figs. 9-11). An animal was considered to have achieved this task if it had at least $70 \%$ correct responses on five consecutive days. Approximately half of the $r d 1 / r d 1$ and $C h R r d 1 / r d 1$ mice managed to learn this task after 1-7 weeks.

\section{Optical imaging}

Surgery. After initial anesthesia with $2 \%$ halothane in a $1: 1 \mathrm{O}_{2} / \mathrm{N}_{2} \mathrm{O}$ mixture, the animals received an intraperitoneal injection of 50 $\mathrm{mg} / \mathrm{kg}$ pentobarbital, supplemented by chlorprothixene ( $0.2 \mathrm{mg} / \mathrm{mouse}$, i.m.), atropine $(0.3$ $\mathrm{mg} / \mathrm{mouse}, \mathrm{s.c})$. and dexamethasone $(0.2 \mathrm{mg} /$ mouse, s.c.). In addition, lidocaine ( $2 \%$ Xylocaine jelly) was applied locally to all incisions. A tracheotomy was performed and the animals were placed in a stereotaxic apparatus. Anesthesia was maintained with $0.6-0.8 \%$ halothane in a mixture of $1: 1$ $\mathrm{O}_{2} / \mathrm{N}_{2} \mathrm{O}$ applied through the tracheal tube. Body temperature was maintained at $37^{\circ} \mathrm{C}$ and electrocardiographic leads were attached to monitor the heart rate continuously throughout the experiment. A craniotomy was prepared over the visual cortex of the left hemisphere. Low-melting point agarose (2.5\% in saline) and a glass coverslip were placed over the exposed area.

Optical imaging. Mouse visual cortical responses were recorded using the imaging method developed by Kalatsky and Stryker (2003). In this method, a temporally periodic stimulus is continuously presented to the animal and the cortical response at the stimulus frequency is extracted by Fourier analysis. Briefly, optical images of cortical intrinsic signals were obtained using a Dalsa 1M30 CCD camera (Dalsa, Waterloo, Canada) controlled by custom software. Using either a $135 \mathrm{~mm}$ x $50 \mathrm{~mm}$ or a 50 $\mathrm{mm} \times 50 \mathrm{~mm}$ tandem lens configuration (Nikon), we imaged a cortical area of $4.6 \times 4.6 \mathrm{~mm}^{2}$ (one hemisphere) or $12.3 \times 12.3 \mathrm{~mm}^{2}$ (both hemispheres). The surface vascular pattern and intrinsic signal images were visualized with illumination wavelengths set by a green (550 \pm 2 $\mathrm{nm})$ or red $(610 \pm 2 \mathrm{~nm})$ interference filter, respectively. After acquisition of a surface image, the camera was focused $600 \mu \mathrm{m}$ below the pial surface. An additional red filter was interposed between the brain and the $\mathrm{CCD}$ camera. Frames were acquired at a rate of $30 \mathrm{~Hz}$ temporally binned to $7.5 \mathrm{~Hz}$ and stored as $512 \times 512$ pixel images after spatial binning of the camera image.

Visual stimuli. To display visual stimuli a high refresh rate monitor (Hitachi Accuvue HM 4921-D, $1280 \times 1024$ at $100 \mathrm{~Hz}$ ) was placed either in front of the animal or in the right visual field at a distance of $25 \mathrm{~cm}$ (see 
Fig. 9). Drifting horizontal or vertical bars ( $4^{\circ}$ wide) were generated by a Matrox G450 board (Matrox Graphics, Quebec, Canada), controlled by custom software. The drifting bars were shown across the full screen, covering $79^{\circ}$ azimuth and $58^{\circ}$ elevation, and their luminance was 60 $\mathrm{cd} / \mathrm{m}^{2}$ on a background of $0.01 \mathrm{~cd} / \mathrm{m}^{2}$.

\section{Data analysis}

Maps were calculated from the acquired frames by Fourier analysis to extract the signal at the stimulation frequency using custom software (Kalatsky and Stryker, 2003). While the phase component of the signal is used for the calculation of retinotopy, the amplitude component represents the intensity of neuronal activation (expressed as fractional change in reflectance $\times 10^{4}$; see Cang et al., 2005 for details). For group comparisons, the strongest elevation map induced by 10 min of visual stimulation in each animal was statistically analyzed. For quantifying the dependence of visual cortical activity on azimuthal position, activity maps were thresholded at $30 \%$ of peak activity and divided into bins of $2^{\circ}$ from $0^{\circ}$ to $79^{\circ}$ azimuth by using the azimuthal phase maps. The amplitudes of all pixels within each bin were summed and multiplied by the pixel area $\left(79 \mu \mathrm{m}^{2}\right)$, resulting in a "volume" of each $2^{\circ}$-bin. Values were then expressed as percentage of total azimuth map "volume." For statistical comparison, 10 bins each were merged into bins of $20^{\circ}$ corresponding to screen quarters.

\section{Behavioral responses and optical imaging at high} stimulus intensities

For testing the visual performance of the animals at high stimulus intensities, the two monitors at the end of the VWT pool were replaced by two transparent screens. Gratings or uniform fields were projected onto the screens by two identical video projectors (Acer P1266P, XGA projector, 2700 ANSI Lumen, 2700:1 contrast). They were powered by 150 W UHP lamps (Derra et al., 2005). All three channels of the projectors were used (RGB white). This represents a stronger stimulus for ChR2-expressing ganglion cells than the blue channel in isolation, because the shortwavelength tail of the green channel also activates ChR2. The maximum illumination of the mice in the VWT pool was 3000 lux, and the maximum brightness of the screen was $15,000 \mathrm{~cd} / \mathrm{m}^{2}$. This is roughly 100 times brighter than the intensity of the monitors used above. First, static gratings ( 0.075 cycle/degree; bright bars: $12,300 \mathrm{~cd} / \mathrm{m}^{2}$; dark bars: 50 $\mathrm{cd} / \mathrm{m}^{2}$ ) were tested against uniform bright fields of the same average intensity. In a second set of experiments a bright field $\left(14,500 \mathrm{~cd} / \mathrm{m}^{2}\right)$ was tested against a dark field $\left(15 \mathrm{~cd} / \mathrm{m}^{2}\right)$. Finally moving gratings ( 0.075 cycle/degree; bright bars: $12,300 \mathrm{~cd} / \mathrm{m}^{2}$; dark bars: $50 \mathrm{~cd} / \mathrm{m}^{2}$; speed: $12 \%$ ) were tested against uniform bright fields of the same average intensity.

For optical imaging at high stimulus intensities the monitor for generating the light stimuli was replaced by a video projector (Acer P1266P) and the patterns were projected onto a transparent screen in front of the animals (bright bars: $12,300 \mathrm{~cd} / \mathrm{m}^{2}$; background: $15 \mathrm{~cd} / \mathrm{m}^{2}$ ).

\section{Statistical analyses}

All intergroup comparisons were done by Student's two-tailed $t$ test. The levels of significance were set as ${ }^{\star} p<0.05$; $^{* *} p<0.01$; $^{* *} p<0.001$. Data are represented as means \pm SEM.

\section{Results}

Expression of ChR2-YFP in ganglion cells of the mouse retina In the transgenic mouse line expressing ChR2-YFP under the control of the Thyl promoter (Arenkiel et al., 2007), prominent YFP fluorescence was found in the ganglion cell layer of the retina. Ganglion cells and their axons pointing to the optic nerve head showed endogenous YFP fluorescence (Fig. $1 B$ ). The cells occurred at high density and were homogeneously distributed all over the retina. However, for further analysis and double immunolabeling experiments antibodies against GFP that recognize also YFP were used to study the expression of ChR2-YFP in the retina.

In vertical sections through the mouse retina (Fig. $1 A$ ) expression of ChR2-YFP is restricted to cell bodies in the ganglion cell

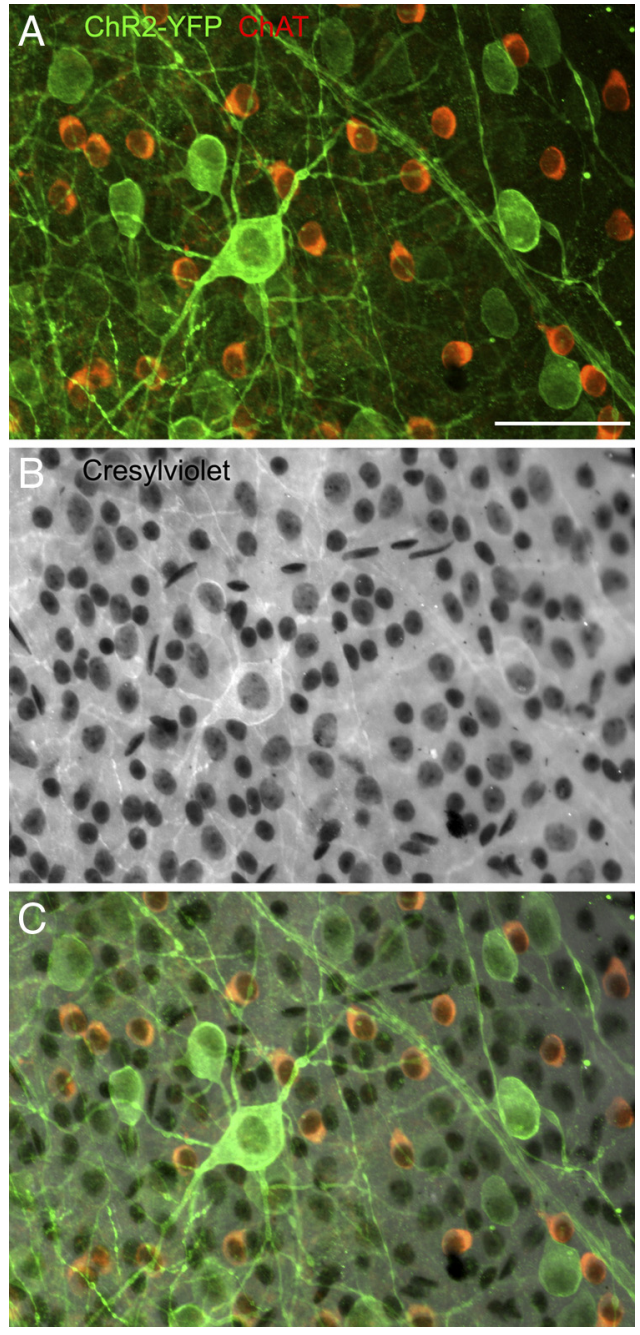

Figure 2. Approximately one third of the ganglion cells in our ChR2rd1/rd1 mice express ChR2-YFP. A, Retinal whole mount double immunolabeled for ChR2-YFP (green) and ChAT (red). ChAT-immunoreactive amacrine cells do not express ChR2-YFP. B, Same field as in $\boldsymbol{A}$, counterstained for cresyl violet. Many more ganglion cells and displaced amacrine cells become apparent. $\boldsymbol{C}$, Superposition of $\boldsymbol{A}$ and $\boldsymbol{B}$. From such material the percentage of labeled ganglion cell could be defined. Scale bar, $50 \mu \mathrm{m}$.

layer (GCL), their dendrites in the inner plexiform layer (IPL) and their axons in the optic nerve fiber layer (NFL). Two prominent bands of labeled dendrites in the IPL represent the ON and OFF strata (Fig. 1A), which suggests that both ON- and OFFganglion cells express ChR2-YFP. In flat view, several types of putative ganglion cells are labeled (Fig. 1C) as indicated by the different dimensions of their cell bodies and the shapes of their dendritic trees (Sun et al., 2002). When the plane of focus is shifted to the amacrine cell layer a sparse population of cell bodies was labeled (data not shown). We interpret these sparse somas to be displaced ganglion cells (Dräger and Olsen, 1980).

In the ganglion cell layer of the mouse retina many displaced amacrine cells are found in addition to ganglion cells (Jeon et al., 1998; Pérez De Sevilla Müller et al., 2007). The major portion of the displaced amacrine cells are the ON-cholinergic (starburst) amacrine cells. To study whether displaced amacrine cells express ChR2-YFP we triple labeled retinal whole mounts for GFP, for ChAT and for cresyl violet (Fig. 2A-C). As shown in Figure $2 A$, cholinergic amacrine cells do not express ChR2-YFP, while several different types of putative ganglion cells exhibit green ChR2- 

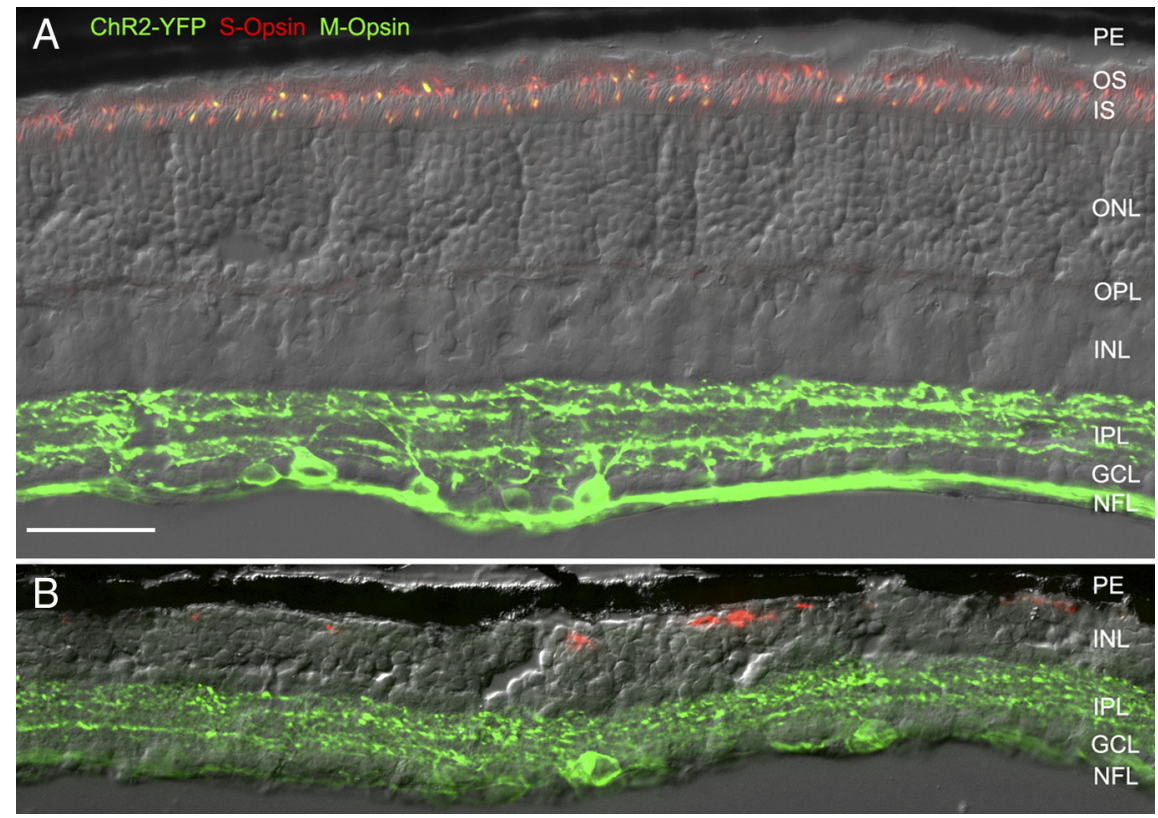

Figure 3. Expression of S-opsin, M-opsin and ChR2-YFP in the wild-type and $r d 1 / r d 1$ mouse retina. $A$, Vertical section through the ventral retina of a wild-type mouse. S-opsin (red) and M-opsin (green) are expressed in the $0 S$ and IS of cones. Many cones express both opsins (yellow). Expression of ChR2-YFP is confined to ganglion cells, their dendrites in the IPL, and their axons in the NFL. $\boldsymbol{B}$, Vertical section through the peripheral retina of a ChR2rd1/rd1 mouse (PND 314). The PE is immediately adjacent to the INL and the photoreceptor layers (ONL, IS, and OS) are completely degenerated. A few cells expressing S-opsin (red) are found at the INL/PE border. ChR2-YFP (green) is expressed in ganglion cells, their dendrites in the IPL and their axons in the NFL. Scale bar, $50 \mu \mathrm{m}$.

YFP fluorescence. In the same piece of retina, stained with cresyl violet (Fig. 2 B), many more cell bodies show up. It is possible to distinguish in cresyl violet stained retinal whole mounts ganglion cell bodies from displaced amacrine cells, glia cells and capillary wall cells, which are all found in the ganglion cell layer (cat: Hughes and Wieniawa-Narkiewicz, 1980: Wässle et al., 1987; mouse: Dräger and Olsen, 1981). Ganglion cells have a pale-blue nucleus with a relatively large nucleolus and granules of pink Nissl substance. Displaced amacrine cells have practically no Nissl-substance and their nucleus has a characteristic nuclear fold. Only the nucleus of glia cells is labeled and has a dark blue appearance. The nuclei of capillary wall cells are elongated and exhibit a dispersed chromatin structure. Based on these criteria, triple labeled retinal whole mounts (Fig. 2C) were analyzed and the following results were found: 1 . cholinergic amacrine cells did not express ChR2-YFP, 2. the density of cholinergic cells is 20\% higher than the density of ChR2-YFP-expressing cells, 3. other displaced amacrine cells do not express ChR2-YFP, 4. between $30 \%$ and $40 \%$ of the ganglion cells express ChR2-YFP. At an eccentricity of 1-2 $\mathrm{mm}$ from the optic disc the density of ChR2YFP cells was $787 \pm 252(n=8)$ cells per $\mathrm{mm}^{2}$. Dräger and Olsen (1980) estimated the density of ganglion cells of the mouse that were retrogradely labeled from the optic tract to be $2680 \pm 231$ $(n=7)$ per $\mathrm{mm}^{2}$, which would confirm that approximately one third of the ganglion cells express ChR2-YFP.

\section{Expression of ChR2-YFP in ganglion cells of the $r d 1 / r d 1$ mouse retina}

To show that the expression of ChR2-YFP in ganglion cells recovers the light sensitivity of retinas lacking cones and rods, we crossbred ChR2-YFP mice with $r d 1 / r d 1$ mice (ChR2 $r d 1 / r d 1)$. Figure $3 A$ shows a section through normal mouse retina (300 d old), triple labeled for GFP (green), S-cone opsin (red) and M-cone opsin (green). Approximately half of the thickness of the retina is made up of photoreceptor cell bodies [outer nuclear layer $(\mathrm{ONL})]$ and their inner (IS) and outer segment (OS). The pigment epithelium (PE) is on top. The cone opsin labeling is restricted to the IS/OS region and many cones express both $\mathrm{M}$ - and S-opsin (yellow fluorescence). Figure $3 B$ shows a section through the retina of a ChR $2 r d 1 / r d 1$ mouse (314 d old). The retina is much thinner than that of a normal mouse (Fig. $3 A$ ), because all the outer retinal layers (ONL, IS and OS) have disappeared due to the degeneration of photoreceptors. A few S-opsin-expressing rudimentary cones can be detected in between the inner nuclear layer (INL) and the PE. However, the expression of ChR2-YFP in the ganglion cell layer is comparable to that of the normal mouse retina (Fig. $3 A, B$ ).

The degeneration of cones and the persistence of ChR2-YFP expression in ganglion cells was studied in more detail in 9 mice of 3 different age groups (110 d: 4 mice; 180 d: 2 mice; 230 d: 3 mice; see Fig. 11). Results from a retinal whole mount from a 235-d-old mouse are shown in Figure 4, $A-F$. The distributions of M-cones, $\mathrm{S}$-cones and ChR2-YFP were studied. The low-power micrograph of the whole mount (Fig. 4C) shows that the few remaining S-cones (in red) are preferentially found in the ventral retina, while remaining $\mathrm{M}$-cones are restricted to the dorsal retina. Selected fields from Figure $4 C$ are shown at higher magnification in Figure 4, $A$ and $E$. The surviving cones have lost their typical appearance and opsin is distributed throughout the cells. From the cell bodies one or more processes originate giving the cells a bipolar or multipolar appearance. Some of the processes terminate in swellings, which are putative presynaptic terminals. This description is in close agreement with a recent light microscopic study of Lin et al. (2009) and electronmicroscopic studies of Blanks et al. (1974). We found a peak density of 692 cells $/ \mathrm{mm}^{2}$ for M-cones in the dorsal retina and 565 cells $/ \mathrm{mm}^{2}$ for $\mathrm{S}$-cones in the ventral retina. Only 13 cones $/ \mathrm{mm}^{2}$ remained in the central retina. The whole mount in Figure $4 C$ was also immunostained for ChR2-YFP which causes the green background fluorescence. The three fields from dorsal, central and ventral retina are shown, with the focus on the GCL/IPL border, at highermagnification in Figure $4, B, D$, and $F$. The dense plexus of dendrites of ganglion cells shows that ChR2-YFP is expressed in the ChR2rd1/rd1 mouse retina and appears not to be altered by the degeneration of photoreceptors. Most importantly, while all photoreceptors are degenerated in the central retina, ganglion cells in that region (Fig. 4D) express ChR2-YFP. Light responses of ganglion cells of the central retina must therefore be intrinsic light responses based on the expression of ChR2-YFP. They were investigated by the following physiological experiments.

\section{Light responses of ChR2-YFP-expressing ganglion cells}

The degeneration and death of both S- and M-cones in $r d 1 / r d 1$ mice advances from the central to the peripheral retina. By postnatal day 90 (P90) remaining cones are restricted to the peripheral retina (Lin et al., 2009). To record intrinsic light responses of 
ChR2-YFP-expressing ganglion cells, we targeted the recording electrode to ganglion cells of the central retina of ChR $2 r d 1 / r d 1$ mice. Action potentials were recorded in the cell attached mode and afterward selected cells were filled in the whole-cell mode with Lucifer yellow (LY) or Alexa Fluor 568 hydrazide (Fig. 5). Figure 5, $A-\mathrm{C}$, shows a cell that has the typical appearance of an OFF-transient cell (Pang et al., 2003; Murphy and Rieke, 2006; Margolis and Detwiler, 2007; van Wyk et al., 2009). It has the classic Alpha cell morphology defined by a large soma $(>20 \mu \mathrm{m}$ diameter) with radial dendrites (Fig. $5 A$ ) and a dendritic field diameter of $\sim 200$ $\mu \mathrm{m}$ (Peichl et al., 1987). To reveal the level of stratification of this cell the retina was immunostained for ChAT and the two cholinergic strata in the OFF- and ONsublamina of the IPL became apparent (Fig. $5 B, C$ ). The level of stratification of this ganglion cell is between the cholinergic strata, close to the OFF-stratum. All this together suggests the cell represents a typical OFF-transient cell (Margolis and Detwiler, 2007; van Wyk et al., 2009). However, the light responses recorded from this cell were sustained and the cell fired at light $\mathrm{ON}$ and not at light $\mathrm{OFF}$ (Fig. 5D): Light responses were recorded from a total of 41 ganglion cells in altogether 6 retinal whole mounts and all were $\mathrm{ON}$ center responses. None of the cells filled with LY had the appearance of melanopsin containing ganglion cells (Berson et al., 2002) and all cells tested expressed ChR2-YFP (supplemental Fig. 2, available at www.jneurosci.org as supplemental material). We therefore conclude that the light responses are based on the expression of ChR2-YFP and represent intrinsic light responses of the ganglion cells.

The ChR2-YFP-mediated light responses differed between different cells, some showed more sustained responses (Fig. 6A, C), and others more transient responses (Fig. 6B,D). This suggests that intrinsic properties of the ganglion cell membranes can shape their sustained/transient characteristics in the ChR2rd1/ $r d 1$ mouse retina (Bi et al., 2006). However, in the intact retina both the intrinsic properties of the ganglion cell membranes as well as synaptic inputs specify the sustained or transient light responses of a given ganglion cell type. In the ChR $2 r d 1 / r d 1$ mice the synaptic input remains static and a ganglion cell can acquire different physiological characteristics. The transformation of the OFF-transient cell of Figure 5 into an ON-sustained cell is an example for such a change, which will be discussed later in more detail.

Light responses of ChR2-YFP-expressing ganglion cells responded well to flickering light stimuli (Fig. $7 A-D$ ) up to frequencies of $16 \mathrm{~Hz}$. This suggests that the cells are suited to transfer fast changing light signals. The fast light responses also support the notion that the recorded cells are not the melanopsin ganglion cells, which have very slow light responses in $r d 1 / r d 1$ mice (Berson et al., 2002).
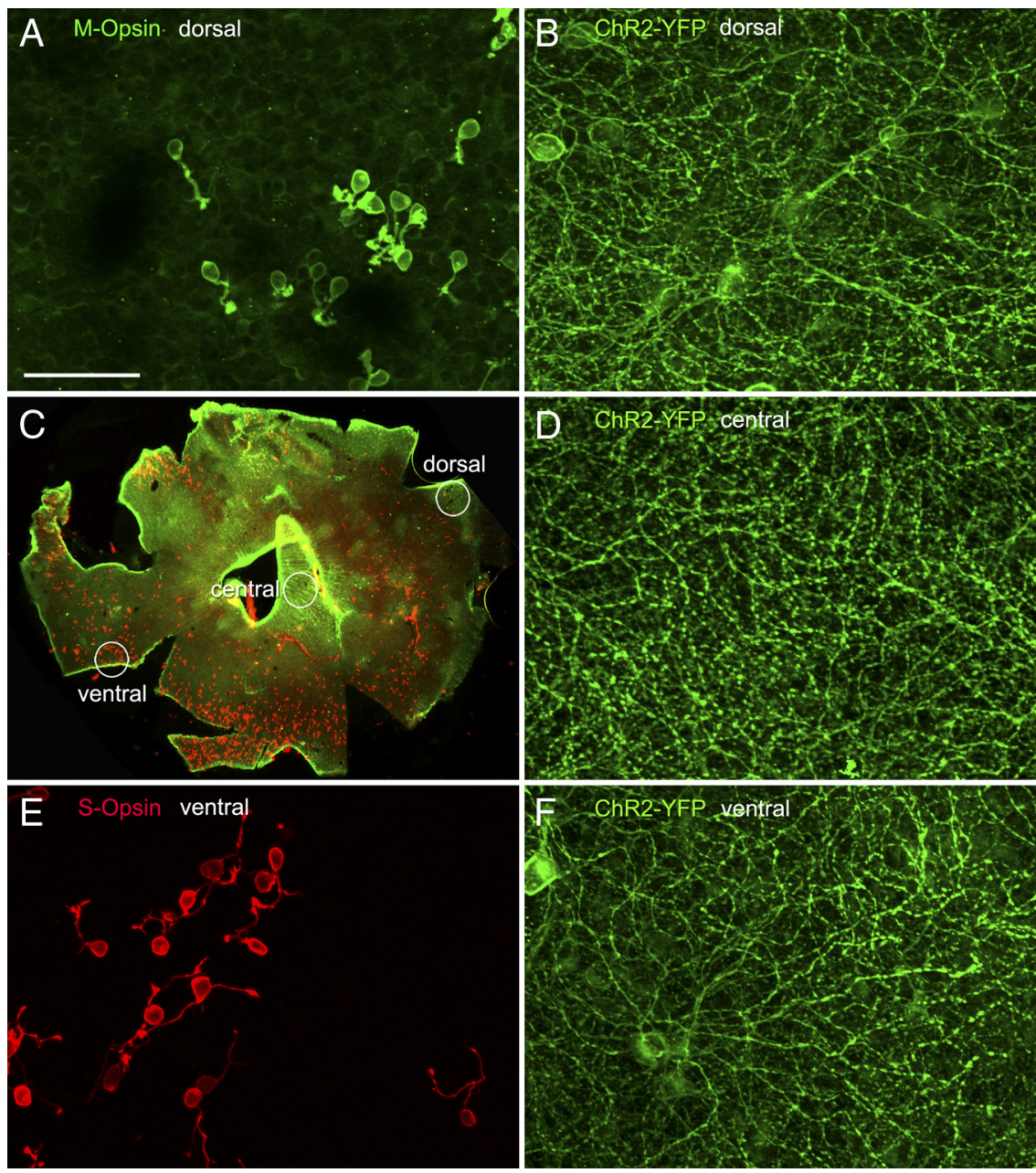

Figure 4. Expression of S-opsin, M-opsin and ChR2-YFP in a whole mount of a ChR2rd1/rd1 mouse retina (PND 235) , Low-power map of the whole mount. At this magnification only the S-opsin expression (red) can be detected. The density dorsal expressed in the ganglion cells. $\boldsymbol{E}$, $S$-opsin expression in rudimentary cones of the ventral retina. $\boldsymbol{F}$, ChR2-YFP expression in the IPL/GCL of the same field as in $\boldsymbol{E}$. Scale bar (in $\boldsymbol{A}$ ): $\boldsymbol{A}, \boldsymbol{B}, \boldsymbol{D}-\boldsymbol{F}, 50 \mu \mathrm{m} ; \boldsymbol{C}, 1 \mathrm{~mm}$.

\section{Light sensitivity of ChR2-YFP-expressing ganglion cells}

Absolute threshold of ganglion cells in wild-type mice

We first measured the sensitivity of ON-sustained, Alpha-like ganglion cells in the central retina of wild-type mice. Figure $8 \mathrm{~A}$ shows the average response of $\mathrm{ON}$-sustained ganglion cell in the completely dark-adapted retina to light stimuli of increasing intensity. The light response from threshold to saturation comprised $\sim 2 \log$ U of intensity (Pang et al., 2003; Völgyi et al., 2004; Murphy and Rieke, 2006: Margolis and Detwiler, 2007). The maximum light response at saturation (average spike rate for the first second after the onset of the stimulus) was $\sim 120$ spikes per second. Figure $8 B$ (left curve) shows the average intensity response function measured from these $\mathrm{ON}$-sustained ganglion cells in the completely dark-adapted retina. The curve has the typical shape of a Michaelis-Menten function (Völgyi et al., 2004). The absolute threshold of the light response is $I=9 \cdot 10^{6}$ photons $/ \mathrm{cm}^{2} / \mathrm{s}$, which is in perfect agreement with the results of Pang et al. (2003) and Völgyi et al. (2004). These latter authors have also shown this to be the lowest threshold of all ganglion cell types in the mouse retina. As tested behaviorally, the absolute 

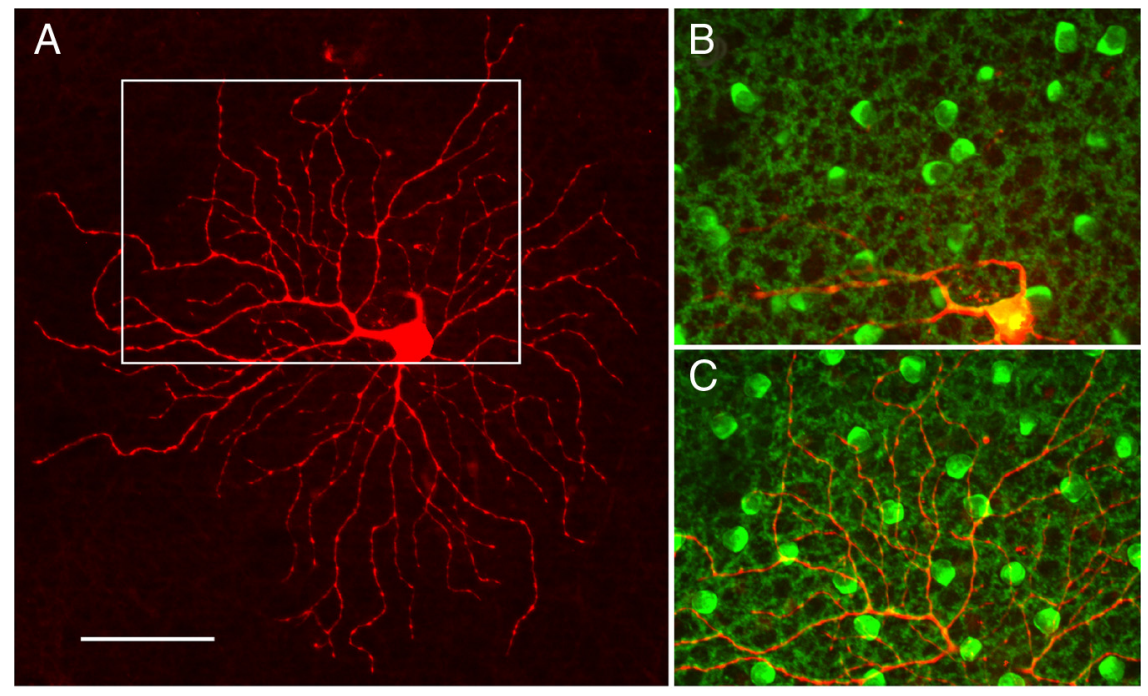

D

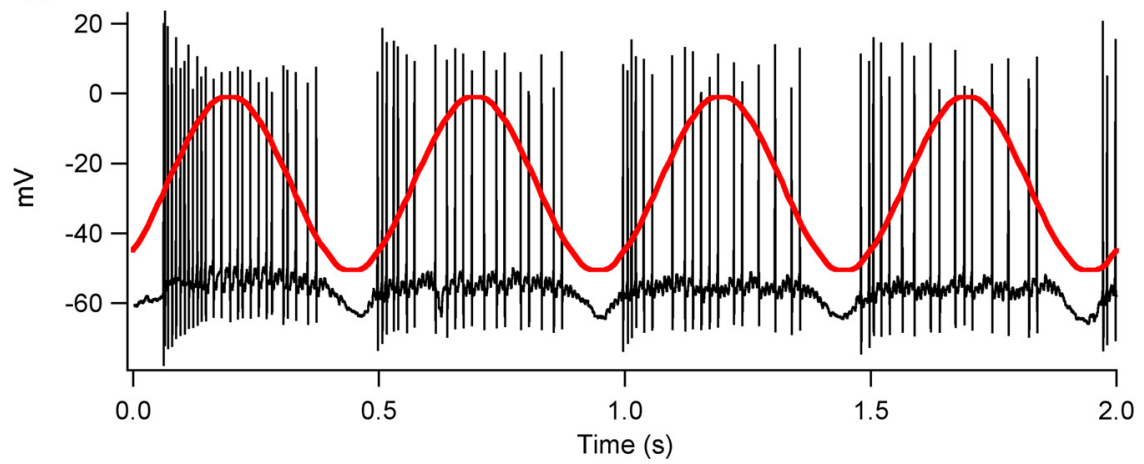

Figure 5. Light responses of a ganglion cell with OFF-transient morphology recorded in the central retina of a ChR2rd1/rd1 mouse. $\boldsymbol{A}$, Whole mount of the retina showing the dendritic tree of the recorded cell, filled with Lucifer yellow after the recordings. The area indicated by the white rectangle is shown at higher magnification in $\boldsymbol{B}$ and $\boldsymbol{C}$ (scale bar, $50 \mu \mathrm{m}$ in $\boldsymbol{A}$ ). The retina was also immunostained for ChAT and the cholinergic cell bodies and their dendrites in the OFF- and ON-stratum of the IPL became apparent. $\boldsymbol{B}$, This micrograph shows a collapsed stack of confocal sections from the cell bodies of ChAT cells in the ganglion cell layer until the center of the IPL. The dendrites of the filled cell are not in focus. $\boldsymbol{C}$, This micrograph shows a collapsed stack of confocal sections from the center of the IPL until the cell bodies of ChAT cells in the amacrine cell layer. The dendrites of the ganglion cells are within this stack and, therefore, stratify in the OFF-sublamina of the IPL. D, Spike-responses of this cell to a sinusoidally modulated light spot. The cell fires at light ON, although it has an OFF-morphology.

visual threshold of wild-type mice is $3.2 \cdot 10^{-6} \mathrm{~cd} / \mathrm{m}^{2}$ (Herreros de Tejada et al., 1997). Assuming that this corresponds to the absolute threshold of $9 \cdot 10^{6}$ photons $/ \mathrm{cm}^{2} / \mathrm{s}$ on the retinal surface, $1 \mathrm{~cd} / \mathrm{m}^{2}$ corresponds to a retinal illumination of $2.8 \cdot 10^{12}$ photons $/ \mathrm{cm}^{2} / \mathrm{s}$ in the completely dark-adapted retina. The mouse pupil area at photopic illumination is only about $10 \%$ of the area a scotopic illumination (Lucas et al., 2001). Therefore, under photopic conditions $1 \mathrm{~cd} / \mathrm{m}^{2}$ corresponds to $2.8 \cdot 10^{11}$ photons $/ \mathrm{cm}^{2} / \mathrm{s}$. This result will be used later to convert the brightness of stimuli in behavioral studies (measured in $\mathrm{cd} / \mathrm{m}^{2}$ ) into retinal illumination (photons $/ \mathrm{cm}^{2} / \mathrm{s}$ ).

Photopic responses of ganglion cells in wild-type mice We also measured, with the same set up, the cone driven input of ON-sustained cells in wild-type retinas by increasing the background and stimulus intensities, while keeping the contrast of 0.96 constant (Fig. $8 \mathrm{~A}$, middle column). The intensity range chosen corresponds to the behavioral studies reported later. However, it has to be emphasized that these measurements are only a first approximation of the cone responses, because the retinal whole mounts from which the light responses were measured were dissected from the pigment epithelium. Therefore, bleach- ing of cone pigment imposes a serious problem at higher light intensities, and it is possible that the maximum spike rate for saturating light intensities is underestimated. The threshold of this cone driven response was $I_{\max }=2.5 \cdot 10^{12}$ photons/ $\mathrm{cm}^{2} / \mathrm{s}$ (Fig. $8 \mathrm{~B}$, middle curve).

\section{Light responses of ganglion cells in ChR2} rd1/rd1 mice

At a photopic background intensity the light responses of ganglion cells from the central retina of ChR $2 r d 1 / r d 1$ mice were measured (Fig. $8 \mathrm{~A}$, right column). The cells were spontaneously active (Dräger and Hubel, 1978; Margolis et al., 2008; Stasheff, 2008). The threshold of the light response was $I_{\max }=1.2 \cdot 10^{14}$ photons/ $\mathrm{cm}^{2} / \mathrm{s}$ and the response did not saturate up to a stimulus intensity of $\sim 1 \cdot 10^{15}$ photons $/ \mathrm{cm}^{2} / \mathrm{s}$. For technical reasons we were not able to test higher light intensities, and the intensity response function is therefore truncated (Fig. $8 \mathrm{~B}$, right curve). The results show that light responses of ganglion cells of the ChR $2 r d 1 / r d 1$ mouse retina are $\sim 2 \log U$ less sensitive than cone driven light responses of wild-type mice measured at photopic background intensities.

\section{Light-induced cortical function and} behavior under normal daylight conditions We tested whether under normal daylight conditions $\left(\sim 100 \mathrm{~cd} / \mathrm{m}^{2}\right)$, expression of ChR2 in ganglion cells can restore visual functions in $r d 1 / r d 1$ mice. The light stimuli applied were between 1 and $100 \mathrm{~cd} / \mathrm{m}^{2}$ which corresponds, as shown above, to a retinal illumination of $2.8 \cdot 10^{11}$ and $2.8 \cdot 10^{13}$ photons $/ \mathrm{cm}^{2} / \mathrm{s}$. This would be in the sensitivity range of photopic, cone driven responses (Fig. $8 B$, middle curve) but below the activation of ChR2-mediated light responses (Fig. $8 B$, right curve).

The visual functions of ChR $2 r d 1 / r d 1$ and $r d 1 / r d 1$ mice were tested by two approaches. We combined both behavioral measurements of visual capabilities and optical imaging of intrinsic signals in the visual cortex (Kalatsky and Stryker, 2003) in individual animals of both strains (Lehmann and Löwel, 2008). The experiments were performed on mice 100 to $250 \mathrm{~d}$ old and were experimenter blind studies. In approximately half of the mice tested, the residual cone density in the retina was measured after the experiments. Three types of behavioral tests were performed: measurements of the optomotor response, the visual acuity and the light/dark discrimination (Prusky et al., 2000; Prusky and Douglas, 2004; Prusky et al., 2004).

A pupil-light reflex was observed in all animals tested. Optomotor responses could not be elicited in $r d 1 / r d 1$ or ChR $2 r d 1 / r d 1$ mice (Schmucker et al., 2005). The visual acuity of the mice was tested in the VWT (Prusky et al., 2004). The animals had to learn the discrimination of a grating stimulus from a uniform gray area of the same brightness. The criterion of $70 \%$ correct responses was not reached even for very coarse gratings and long training 
periods. The only behavioral test which was learned by mice of both strains was the discrimination of bright and dark stimuli. The training time it took for the animals to reach the criterion of $70 \%$ correct responses was taken as the visual performance. Figure $9 A$ shows the learning curve of a ChR $2 r d 1 / r d 1$ mouse, 223 d old. After $4 \mathrm{~d}$ of training this mouse reached the criterion $(70 \%)$ for the first time and thereafter could reliably discriminate the bright and dark fields. Learning curves of 8 additional mice in the VWT are compared in supplemental Figure 3 (available at www.jneurosci.org as supplemental material). It can be seen that both $r d 1 / r d 1$ and ChR2rd1/rd1 mice showed strong variability in reaching the $70 \%$ criterion, but that animals of both genotypes completed the test successfully. Five of nine $r d 1 / r d 1$ animals $(56 \%)$ and six of 10 ChR $2 r d 1 / r d 1$ (60\%) reached the criterion within 3- $47 \mathrm{~d}$ of training. On average, ChR2 $r d 1 / r d 1$ mice learned faster and needed $18 \pm 5 \mathrm{~d}$ to reach the criterion while $r d 1 / r d 1$ mice needed $26 \pm 4 \mathrm{~d}$ (Fig. $10 A)$. This difference was, however, not statistically significant $(p=0.27)$.

After these behavioral studies, visual cortical activity was analyzed and quantified using intrinsic signal optical imaging (Fig. 9B). The stimulation screen (height $58^{\circ}$ width $79^{\circ}$ ) was placed in front of the animals or in the right visual field. A light bar was periodically moving up and down (elevation map) or left to right (azimuth map) and the evoked intrinsic signals were measured (for further details see $\mathrm{Ma}$ terials and Methods). The phase component of the signal was used for the calculation of retinotopy, the amplitude represents the intensity of neuronal activation (expressed as fractional change in reflectance $\times 10^{4}$ ). The position of the stimulation screen with respect to the mouse eyes is shown on top of Figure $9 B$. The upper color coded maps show the response magnitude and its position in the visual field (polar maps). The lower color coded maps show the retinotopy of visual cortical activation. The lower black and white images represent gray-scale coded response magnitude maps, illustrating the intensity of neuronal activation according to the gray scale on the right side of the figure. The maximal map amplitude was $1.02 \times 10^{-4}$.

Visual stimulation induced activity maps in the visual cortex of both ChR $2 r d 1 / r d 1$ and $r d 1 / r d 1$ mice. In $80 \%$ of the ChR $2 r d 1 /$ $r d 1$ and in $90 \%$ of the $r d 1 / r d 1$ mice activity maps could be elicited. To compare the intensity of cortical activation in the two genotypes, we determined the maximal amplitudes of elevation maps after $10 \mathrm{~min}$ of visual stimulation (Fig. $11 \mathrm{~B}$ ). The average map amplitude was $0.82 \pm 0.09 \times 10^{-4}$ in ChR2rd1/ $r d 1$ mice $(n=8)$ and $0.64 \pm 0.07 \times 10^{-4}$ in $r d 1 / r d 1$ animals

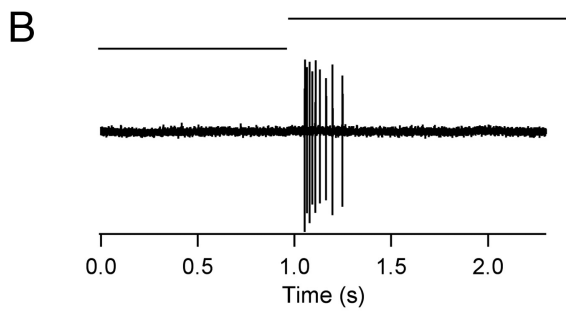

D

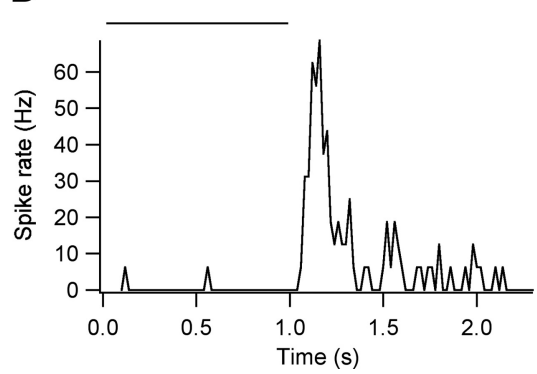

Figure 6. Light responses of ganglion cells recorded in the central retina of a ChR2 $r d 1 / r d 1$ mouse. $\boldsymbol{A}$, This cell showed a short-latency, sustained increase of the firing rate in response to the light stimulus. $\boldsymbol{B}$, This cell showed a short-latency, transient increase of the firing rate. C, A spike-time histogram (STH) showing the average light response of 6 sustained ganglion cells. D, A STH showing the average light response of 3 transient ganglion cells (stimulus intensity: $I_{\max }=1 \cdot 10^{15} \mathrm{photons} / \mathrm{cm}^{2} / \mathrm{s}$; stimulus

A

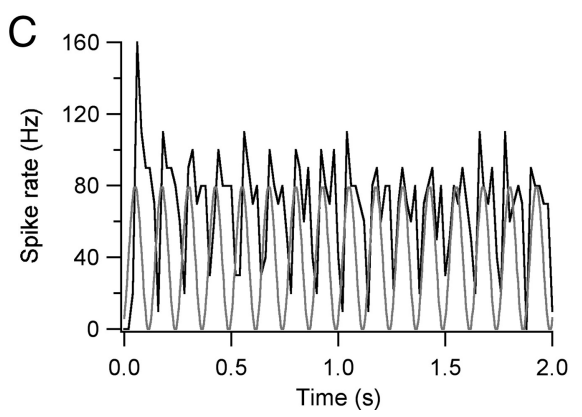

Figure 7. Spike-time histograms of the light responses of a ganglion cell from the central retina of a ChR2 $r d 1 / r d 1$ mouse. Light intensity was modulated in a sinusoidal fashion at $2 \mathrm{~Hz}(\boldsymbol{A}), 4 \mathrm{~Hz}(\boldsymbol{B}), 8 \mathrm{~Hz}(\boldsymbol{C})$, and $16 \mathrm{~Hz}$ (D; spot size $120 \mu \mathrm{m}$; intensity: $I_{\max }=$ $1 \cdot 10^{15}$ photons $/ \mathrm{cm}^{2} / \mathrm{s}$ ). $(n=8)$. Visual cortical activation was thus higher in ChR $2 r d 1 /$ $r d 1$ compared with $r d 1 / r d 1$ animals, but this difference was not significant ( $p=0.13$ ).

As cone degeneration proceeds from the central to the peripheral retina in $r d 1 / r d 1$ mice (Lin et al., 2009), we wondered whether cortical activity induced by stimuli in the visual field center was smaller compared with more peripheral visual stimuli. To this end (Fig. 10), we quantified cortical response amplitude along the azimuthal axis from $0^{\circ}$, precisely in front of the animal (stimulating the peripheral retina), to $79^{\circ}$, lateral visual field (stimulating the central retina around the optic disc). Azimuth 

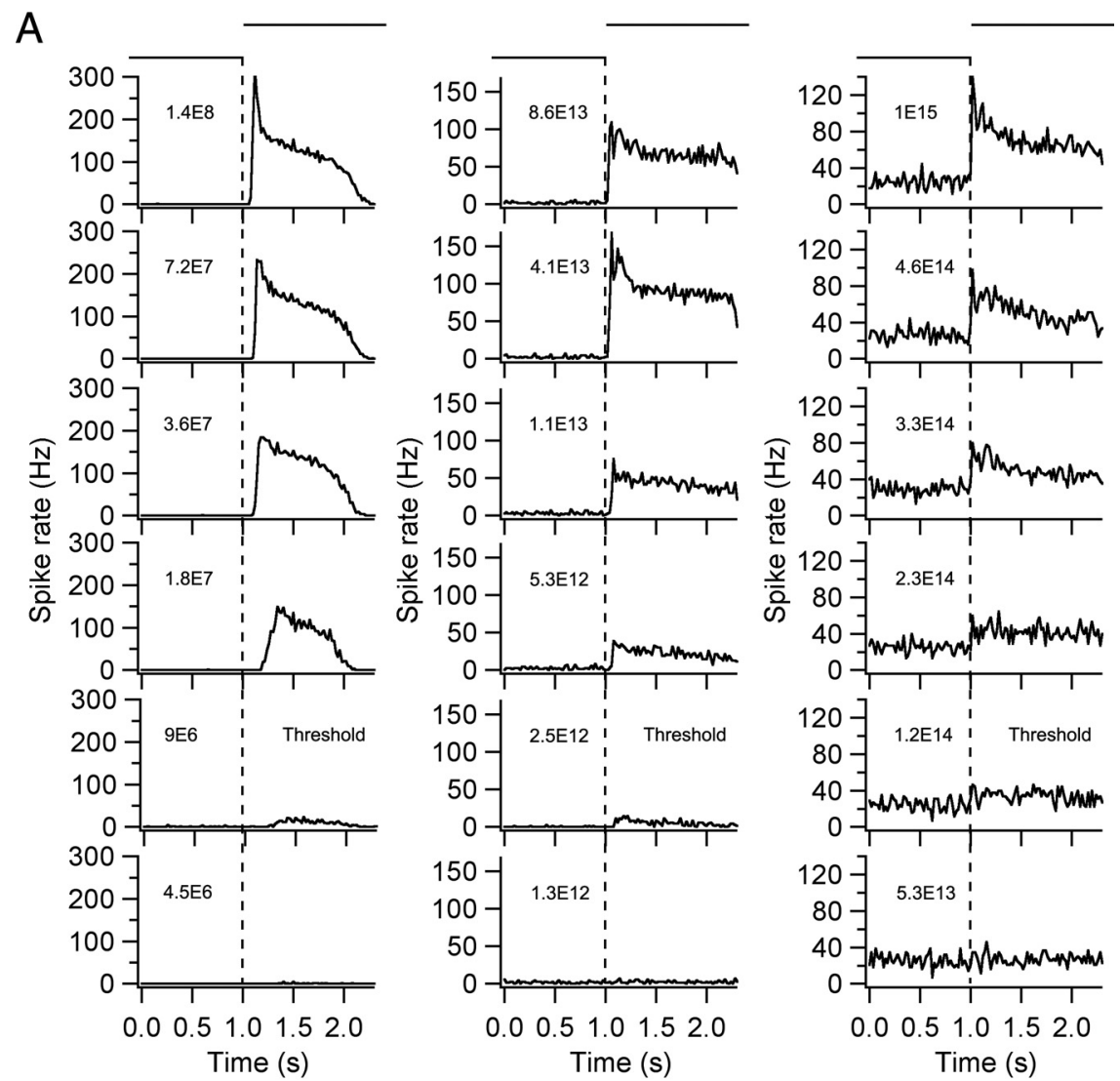

$\mathrm{B}$

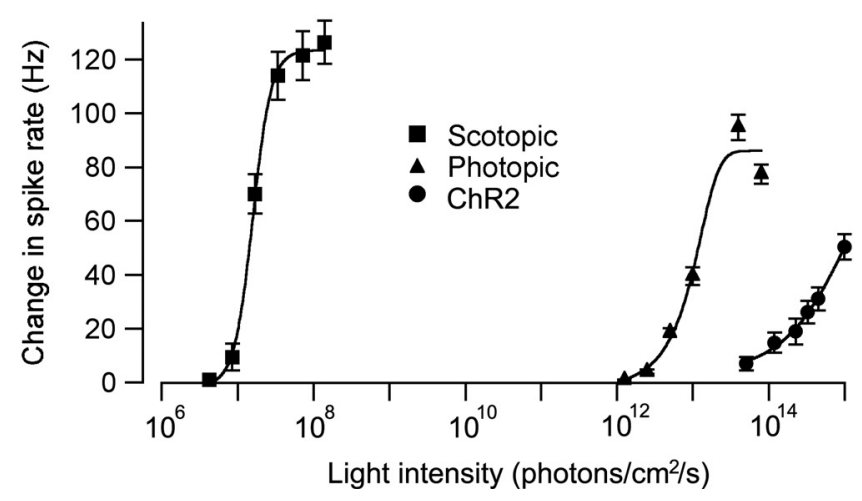

Figure 8. Response functions of ganglion cells to light stimuli of increasing intensity. A, Left column, Average light response of $60 \mathrm{~N}$-sustained ganglion cells of the completely dark-adapted wild-type mouse retina. The stimulus intensity is indicated (photons $/ \mathrm{cm}^{2} / \mathrm{s}$ ), the spot size is $300 \mu \mathrm{m}$. The threshold is $9 \cdot 10^{6}$ photons $/ \mathrm{cm}^{2} / \mathrm{s}$. Middle column, Average light response of 7 ON-sustained ganglion cells of the light-adapted wild-type mouse retina. The threshold is $I_{\max }=2.5 \cdot 10^{12}$ photons $/ \mathrm{cm}^{2} / \mathrm{s}$ (background illumination $I_{\min }=5 \cdot 10^{10}$ photons $/ \mathrm{cm}^{2} / \mathrm{s}$; spot size: $120 \mu \mathrm{m}$ ). Right column, Average light response of 7 ganglion cells of the light-adapted central retina of ChR2rd1/rd1 mice. The cells showed a maintained discharge and the threshold to elicit a response above this maintained discharge was $I_{\max }=1.2 \cdot 10^{14}$ photons $/ \mathrm{cm}^{2} / \mathrm{s}$ (background illumination $I_{\min }=2 \cdot 10^{12}$ photons $/ \mathrm{cm}^{2} / \mathrm{s}$; spot size $120 \mu \mathrm{m}$ ). $\boldsymbol{B}$, Intensity response functions calculated from the light responses in $\boldsymbol{A}$ (average discharge rate for the first second after the onset of the stimulus).

maps of sufficient quality for quantification were obtained from three $r d 1 / r d 1$ and two ChR2 $r d 1 / r d 1$ mice. Visual cortical activity declined significantly from $0^{\circ}$ to $79^{\circ}$ azimuth (Fig. 10) in four of these animals (two $r d 1 r d 1$ and two ChR $2 r d 1 / r d 1$ ) and on average $\left(R^{2}=0.538, p<0.001\right)$. For statistical analysis we used the magnitude of cortical responses to visual stimulation in each screen quarter, corresponding to $20^{\circ}$ azimuth. Compared with age-matched $\mathrm{C} 57 \mathrm{BL} / 6$ mice $(n=8)$, the right quarter of the screen (corresponding to visual field periphery $60^{\circ}$ to $79^{\circ}$ azimuth) was significantly less represented in $r d 1 / r d 1$ and ChR $2 r d 1 / r d 1$ mice $(p<0.001$, Bonferroni-corrected $t$ test). There was no significant difference between $r d 1 / r d 1$ and ChR2 $r d 1 / r d 1$ mice. These results indicate that visual function in both $r d 1 / r d 1$ and ChR2rd1/rd1 mice was related to cone survival in the degenerating retina.

Following these imaging studies the animals were killed and whole mounts of the retina were triple immunostained for S-opsin, M-opsin and ChR2-YFP. As described previously, hardly any cones were found in the center of the retina, rudimentary $\mathrm{M}$-cones were observed in the dorsal retina and rudimentary S-cone in the ventral retina, their densities being closely comparable. Since S-opsin fluorescence was more intense, and because S-opsin-expressing cones are 3 times more sensitive than $\mathrm{M}$-opsin-expressing cones (Lyubarsky et al., 1999), the peak density of S-opsin-expressing cones was measured. Figure $9 C$ shows the $S$-cones in the lower peripheral retina of the same mouse from which the results in Figure 9, $A$ and $B$, were obtained. Their peak density in far peripheral retina $(2 \mathrm{~mm}$ from the blind spot) was 2143 cones/ $\mathrm{mm}^{2}$. Ganglion cells of this retina expressed ChR2-YFP fluorescence (data not shown).

The summary Figure 11 shows the pooled results from a total of 19 mice (9 $r d 1 / r d 1$ and $10 \mathrm{ChR} 2 r d 1 / r d 1)$ that were studied both in the VWT and by optical recordings of intrinsic light-evoked activity. Both in the VWT (Fig. 11A) and in the optical imaging (Fig. 11B) ChR2rd1/rd1 mice showed a better average performance than $r d 1 / r d 1$ mice. However, the differences were not significant.

The ages of the analyzed mice are illustrated in Figure 11C. On average the $r d 1 /$ $r d 1$ mice were $50 \mathrm{~d}$ older than the ChR2 $r d 1 / r d 1$ mice. This difference is significant at a level of $p=0.059$. Since it is known that fewer cones survive in older animals, we asked whether the behavioral results and the optical imaging amplitudes reflect the age of the animals. Figure $11 \mathrm{D}$ shows that the maximal amplitude of the cortical activity maps decreased with increasing age of the animals, as did cone density (Fig. $11 E$ ). Similarly, with increasing age the time to reach the $70 \%$ criterion increased from approximately $10 \mathrm{~d}$ at postnatal day (PND) 100-40 d at PND 250 (Fig. 11 F). The visual performance is also correlated with the residual S-cone density (Fig. 11G): the lower the cone density the longer it takes the mice to reach the $70 \%$ criterion. In Figure $11, D-G$, results from $r d 1 / r d 1$ and ChR2rd1/rd1 mice are mixed and show a comparable variation with age. This together with the results of Figure 11, $A$ and $B$, suggests that the expression of ChR2-YFP in ganglion cells does not significantly improve the visual performance of the mice. The 

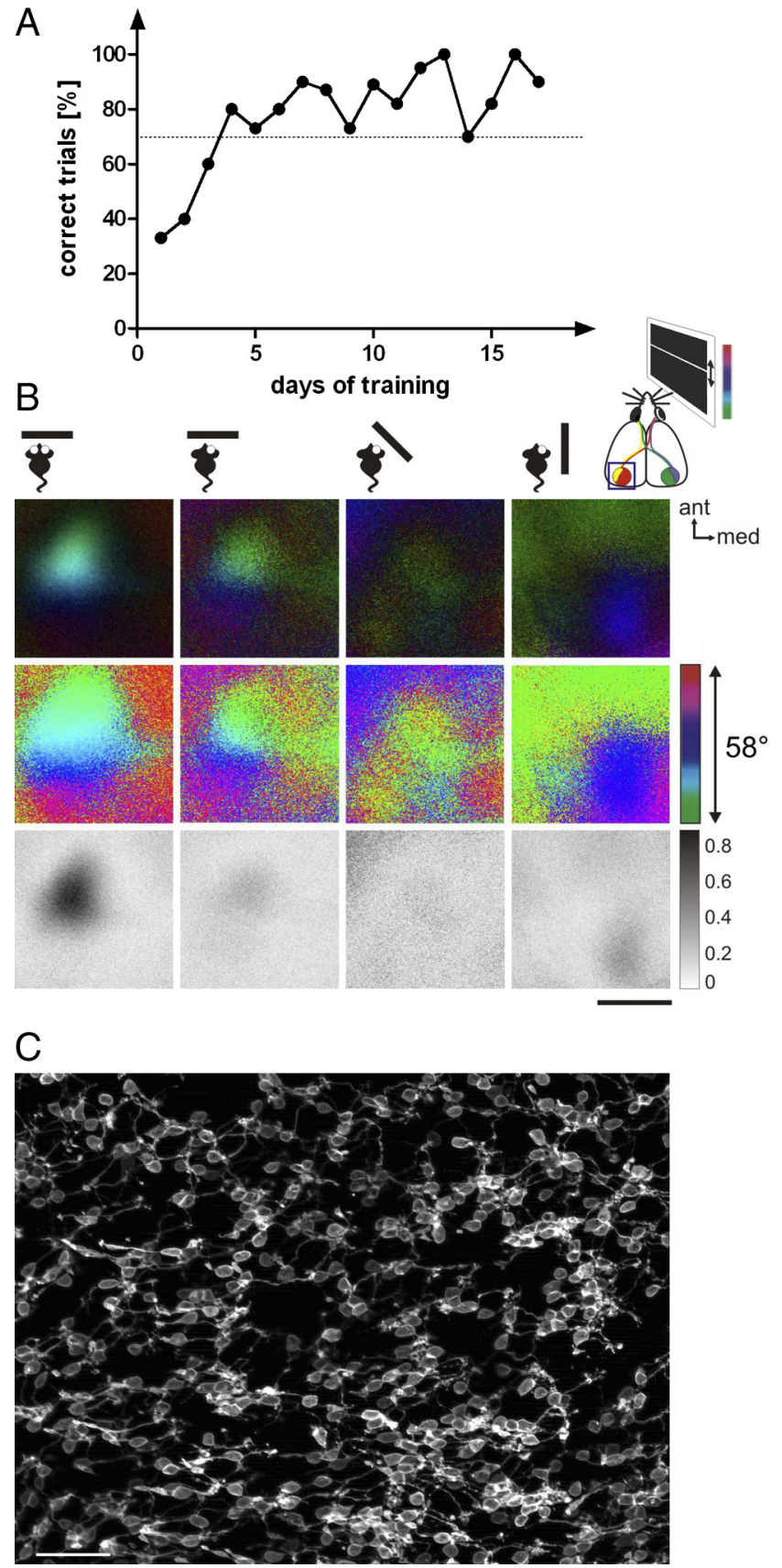

Figure 9. Test of visual performance, cortical activity maps and residual $S$-cone density of the same animal, a ChR2rd1/rd1 mouse, $223 \mathrm{~d}$ old. A, Learning curve of the discrimination of a bright field from a dark field in the VWT. After $4 \mathrm{~d}$ of training the mouse reached the criterion continuously (70\% correct responses). $\boldsymbol{B}$, Optical recording of the activity in the visual cortex of the same animal elicited by the up and down movement of a horizontal bar (see inset). The 4 positions of the stimulus screen and the stimulation conditions (binocular/monocular) are indicated on top and the evoked activities are shown underneath. Upper and middle row, Polar and phase map of the response (retinotopic map); bottom row, gray scale coded magnitude map of the visual cortical responses. The color code and the intensity code are indicated on the right. ant, anterior; med, medial. Scale bar, $1 \mathrm{~mm}$. C, Immunostaining of the residual cones in the ventral retina of the same animal for S-opsin. Their peak density was 2431 cones $/ \mathrm{mm}^{2}$. Scale bar, $50 \mu \mathrm{m}$.

residual vision apparently rather depends on the number of surviving cones.

Light-induced behavior at high stimulus intensities

The behavioral VWT responses and the cortical maps were also tested at stimulus intensities of $>10,000 \mathrm{~cd} / \mathrm{m}^{2}$, which corre- sponds to $>2.8 \cdot 10^{15}$ photons $/ \mathrm{cm}^{2} / \mathrm{s}$ at the level of the retinal ganglion cells. As can be seen from Figure 8 , this is in the response range of ChR2-YFP-expressing ganglion cells.

Three sets of experiments were performed on $5 \mathrm{rd} 1 / \mathrm{rd} 1$ and 6 ChR2rd1/rd1 mice. The genotypes were age matched and between 160 and $240 \mathrm{~d}$ old, when photoreceptors have nearly completely degenerated. Training of the visual water task started with static square wave gratings (for details see methods), which had to be discriminated from equiluminant gray. The animals were tested for $17 \mathrm{~d}$, however, none reached the $70 \%$ criterion for this test (supplemental Fig. 4A, available at www.jneurosci.org as supplemental material). Next the animals were trained for $18 \mathrm{~d}$ to distinguish a uniform bright field from a dark field. The criterion for this test was reached by $5 / 5 r d 1 / r d 1$ mice and by $4 / 6 \mathrm{ChR} 2 r d 1 /$ rd1 mice (supplemental Fig. $4 B$, available at www.jneurosci.org as supplemental material). Since the age-range of the animals was small, no age dependence of the time to reach the criterion was observed (supplemental Fig. 4D, available at www.jneurosci.org as supplemental material). In the third test the animals had to distinguish a moving grating from a uniform background of the same average intensity (supplemental Fig. 4C, available at www. jneurosci.org as supplemental material). None of the animals reached the criterion for this test. Wild-type animals learned all three tests within a few days of training (data not shown).

In conclusion, none of the $r d 1 / r d 1$ or ChR $2 r d 1 / r d 1$ animals could reliably distinguish gratings from uniform gray, independent of whether stimuli were moving or static and no matter how bright the stimuli were. In contrast, mice of both genotypes were able to discriminate bright and dark, which, according to the preceding paragraph (Fig. 11) is most likely a function of the few surviving cones.

\section{Mapping cortical function at high stimulus intensities}

Visual stimulation with high light intensities $(>10,000 \mathrm{~cd} / \mathrm{m} 2)$ induced activity maps in the visual cortices of 3 of $4 \mathrm{ChR} 2 \mathrm{rd} 1 / \mathrm{rd} 1$ and 2 of $3 r d 1 / r d 1$ mice. The average map amplitudes were 0.56 in ChR2 $r d 1 / r d 1$ mice and 0.93 in $r d 1 / r d 1$ mice. The differences in the cortical activation between ChR $2 r d 1 / r d 1$ and $r d 1 / r d 1$ mice were not significant. Moreover, stimulation with high light intensities did not induce more prominent cortical activation than stimulation with moderate intensities (Fig. 10). Although both behavioral VWT responses and cortical activation maps were measured at high stimulus intensities, in a range where ChR2YFP-expressing ganglion cells were activated (Fig. 8), this ChR2expression did neither significantly improve visual cortical activity maps of the mice nor their visual capabilities indicating that residual vision was mediated by the surviving cones.

\section{Discussion}

It was the aim of the present paper to test the ability of ChR2 to restore visual function in $r d 1 / r d 1$ mice and ultimately in humans with progressive degeneration of rods and cones leading to blindness. Several preceding studies have expressed ChR2 in retinal ganglion cells of $r d 1 / r d 1$ mice by viral transfection and demonstrated that visual functions can be restored, however, extremely high light intensities were necessary (Bi et al., 2006; Tomita et al., 2007, 2010; Lagali et al., 2008; Zhang et al., 2009). By generating a transgenic mouse line which expresses ChR2 in $30-40 \%$ of the ganglion cells and by crossbreeding this line with the photoreceptor degeneration mouse line $r d 1 / r d 1$ we created a more homogeneous and standardized "blind" retina compared with the viral transfection experiments. We addressed the question whether ChR2 can rescue vision in this mouse line with normal daylight 

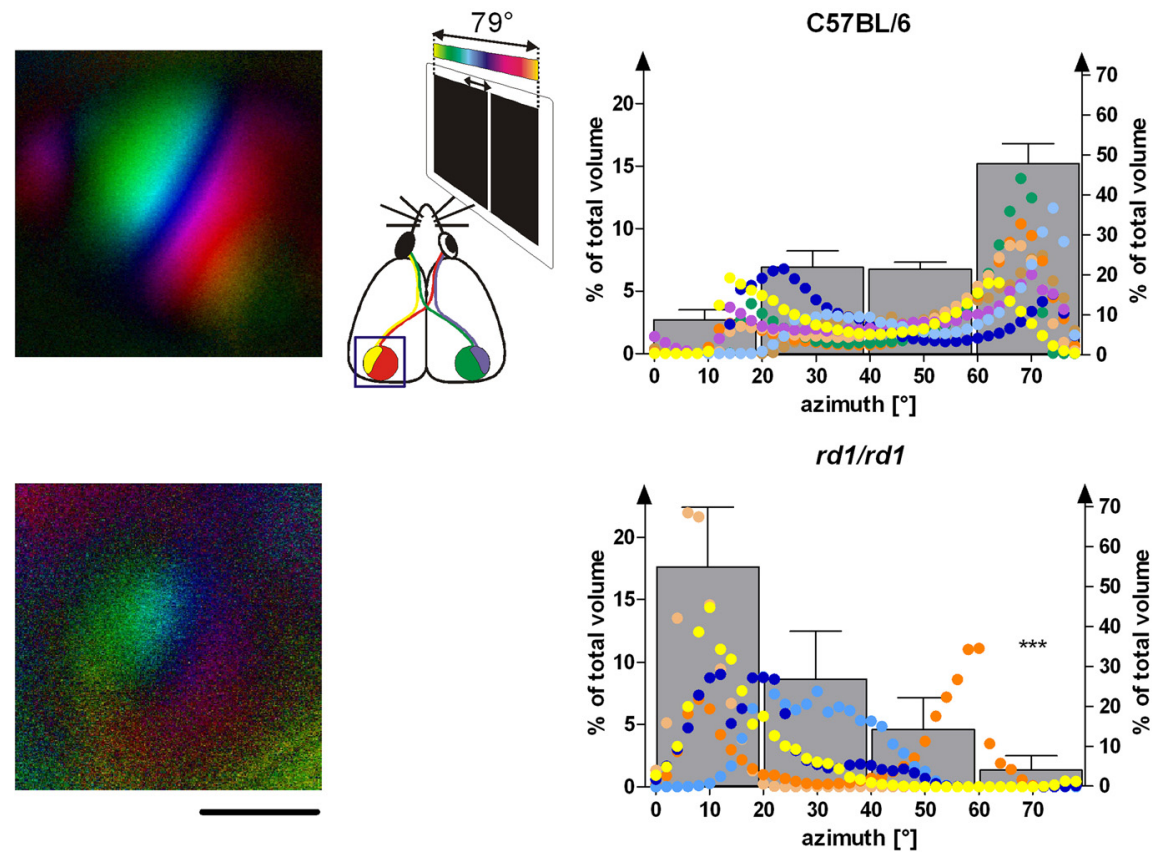

Figure 10. Dependence of cortical activity on azimuthal position of the visual stimulus. Response strength of visual cortex to vertical moving stimuli covering $0^{\circ}$ to $79^{\circ}$ of visual field in azimuth (inset), displayed in steps of $2^{\circ}$ (dot plots, left axis) or $20^{\circ}$ (column plots, right axis) azimuth, and expressed as percentage of total map volume. Data of eight C57BL/6 mice (top), agematched to three $r d 1 /$ rd 1 (yellowish colors) and two ChR2rd1/rd1 (blue colors) are illustrated. In both panels, the yellow dotted line shows the quantification of the representative polar map illustrated on the left. Note that cortical activity declined from visual field position $0^{\circ}$ (stimulating the peripheral/temporal retina) toward $79^{\circ}$ (stimulating the central retina near the optic disk) in $r d 1 / r d 1$ mice so that the representation of the central retinal field in $r d 1 / r d 1$ mice is highly significantly weaker than in C57BL/6 mice ( $p<$ 0.001 , Bonferroni-corrected $t$ test). Scale bar, $1 \mathrm{~mm}$.

levels of illumination $\left(\sim 100 \mathrm{~cd} / \mathrm{m}^{2} ; 2.8 \cdot 10^{13}\right.$ photons $\left./ \mathrm{cm}^{2} / \mathrm{s}\right)$, and at very high light intensities $\left(>10,000 \mathrm{~cd} / \mathrm{m}^{2} ;>2.8 \cdot 10^{15}\right.$ photons $/ \mathrm{cm}^{2} / \mathrm{s}$ ).

All mice tested showed a pupillary-light reflex, independent of age and number of surviving cones. It has been shown that melanopsin containing ganglion cells mediate this reflex even if no photoreceptors are left (Foster and Hankins, 2002). None of the mice tested was able to discriminate gratings from uniform fields (van Alphen et al., 2009). The only visual task successfully passed by both $r d 1 / r d 1$ and ChR $2 r d 1 / r d 1$ mice was the discrimination of a bright field from a dark field. However, ChR2-YFP-expressing mice were not significantly better than $r d 1 / r d 1$ mice and the performance appeared to be related rather to the residual cone density than to the genotype (Fig. 10). Our results thus indicate that ChR2rd1/rd1 mice are more or less blind.

\section{Possible reasons for the failure to restore vision by the expression of $\mathrm{ChR} 2$ in ganglion cells}

The physiological recordings from ganglion cells of the isolated retina of ChR2rd1/rd1 mice (Fig. 8 ) showed that their activation threshold is $1.2 \cdot 10^{14}$ photons $/ \mathrm{cm}^{2} / \mathrm{s}$. The high light intensities of $>2.8 \cdot 10^{15}$ photons $/ \mathrm{cm}^{2} / \mathrm{s}$ applied in the behavioral studies must activate the Chr2-YFP-expressing ganglion cells, however, the visual cortex apparently had no access to this information.

One reason for this "cortical blindness" might be that ChR2YFP, whose expression is driven by the Thy-1 promoter, is not present in a sufficient number of ganglion cells. It is also possible that the well known variegation of the Thy-1 promoter drives expression only in specific types of ganglion cells. Thus, expression of ChR2-YFP could be restricted to those ganglion cells of the mouse retina which project to the superior colliculus and not to the lateral geniculate nucleus and the visual cortex.

Another reason for this apparent cortical blindness might be the distorted physiological signature of the ganglion cells due to the expression of ChR2-YFP. In the normal retina the major subdivision of ganglion cells is into $\mathrm{ON}$ - and OFF-cells. In the present study, and also in the preceding studies using viral transfection and unspecific promoters (CMV promoter: Bi et al., 2006; Tomita et al., 2007, 2010; Lin et al., 2008) all ganglion cells were depolarized by light, regardless of whether they were originally ON- or OFFganglion cells. Thus, all OFF-ganglion cells were transformed into ON-ganglion cells. In the visual cortex simple- and complex- cell receptive fields are made up of spatially segregated, excitatory and inhibitory inputs from thalamic ON- and OFF-afferents (Liu et al., 2010). Transformation of all OFF-cells into ON-cells may thus abolish the receptive field structure in the visual cortex.

Expression of ChR2-YFP in the ganglion cells not only changes their $\mathrm{ON}-/$ OFF-signature; other physiological features of different ganglion cell classes are also distorted. Figure 5 shows a typical OFFtransient ganglion cell, which has transient light responses in the wild-type retina (Margolis and Detwiler, 2007; Münch et al., 2009; van Wyk et al., 2009). However, in the ChR $2 r d 1 / r d 1$ mouse retina the light responses of this cell type are sustained (Fig. 4D). Thus the sustained/transient segregation of ganglion cells can also be distorted in the ChR $2 r d 1 / r d 1$ mouse retina. Similarly it can be expected that direction selective (DS) ganglion cells have lost their specificity in ChR2rd1/rd1 transgenic mice. Thus, the parallel processing of visual signals and the visual channels formed by the different ganglion cell classes (Roska and Werblin, 2001; Wässle, 2004) are disturbed in these mice. Thus, although the visual cortex in these mice received light signals, it obviously could not "read" the distorted code.

\section{Strategies to restore vision by the expression of $\mathrm{ChR2}$}

Lagali et al. (2008) expressed ChR2 under the control of the metabotropic glutamate receptor 6 (mGluR6). Expression was restricted to ON-bipolar cells. They became light-sensitive and in turn activated ON-ganglion cells. Thus the correct physiological responses were transferred to the brain. Recently it was shown that another microbial rhodopsin, halorhodopsin (HaloR), a light driven chloride pump, can be expressed in retinal ganglion cells which are consequently hyperpolarized by light and are OFF-cells (Zhang et al., 2009). This raises the question of what would be the optimal strategy to restore vision by the expression of ChR2 and HaloR. Bipolar cells occur at a high density across the retina and are the most numerous cell type of the primate retina next to rods. Their varicose, compact axon terminals cover the retina without leaving gaps (Wässle et al., 2009). Thus they would provide a better photon catch than the rather loose dendritic trees of ganglion cells. By making bipolar cells light sensi- 
tive, the inner retinal circuitry, which creates specificity, such as direction selective light responses, would stay in operation. Virus vectors have to be constructed which efficiently transfect bipolar cells and promoters have to be found which drive the expression of $\mathrm{ChR} 2$ in $\mathrm{ON}$ bipolar cells and HaloR in OFF-bipolar cells. However, this approach will only work if the light sensitivities of both ChR2 and HaloR are increased and their temporal resolution is compatible with vision.

If these results are applied to the human eye, one has to take into account both the lower optical power and the larger pupil size of the human eye compared with the mouse eye. For these optical reasons a light stimulus would require a brightness of $10^{4} \mathrm{~cd} / \mathrm{m}^{2}$ to optimally stimulate ChR2-expressing ganglion cells of the human retina. Such intensities are encountered in the natural environment on snow in sunlight.

By modern techniques of image intensification it would be possible to amplify moderate light stimuli so they would be able to stimulate $\mathrm{ChR} 2$-expressing ganglion cells. However, it is known that prolonged exposure to strong light causes damage to the retina and results in apoptotic cell death (Remé et al., 1998). Therefore, to avoid retinal damage, the better strategy seems to be to increase the light sensitivity of ChR2 (Greenberg et al., 2010) and use an image transformation (McGovern et al., 2010) so that only brief light-stimuli are applied.

Berndt et al. (2009) have recently applied directed molecular engineering of ChR2 to modify protein residues that are critical for determining the channel kinetics. They changed the Cys 128 residue of ChR2 into C 128A, or C 128S. Following expression of wild-type ChR2 in Xenopus oocytes the threshold of photo currents elicited by blue light was $\sim 1 \cdot 10^{14}$ photons $/ \mathrm{cm}^{2} / \mathrm{s}$, which is identical to the threshold of $1.2 \cdot 10^{14}$ photons measured here for ganglion cells (Fig. 8). In contrast, cells that expressed C128A and C128S were $\sim 300$-fold more sensitive than those expressing wild-type ChR2. Such an increase in light sensitivity would be sufficient to make ChR2 responsive under daylight conditions. Unfortunately the modified ChR2s had a very long open state of the light activated channel $(\mathrm{C} 128 \mathrm{~A}$, tau decay $=52 \mathrm{~s} ; \mathrm{C} 128 \mathrm{~S}$, tau decay $=106 \mathrm{~s})$. This means that the channels stay open for up to $100 \mathrm{~s}$ after switching off the light stimulus so that these ChR2s are not suitable for the restoration of vision. However, the channels can be closed by a second pulse with red shifted light (Berndt et al., 2009). By the application of intelligent image processing devices it might therefore be possible in the future to shine blue light onto the retina as an imaging stimulus and periodically apply red light as a blanking stimulus to increase the temporal resolution of such modified ChR2s.
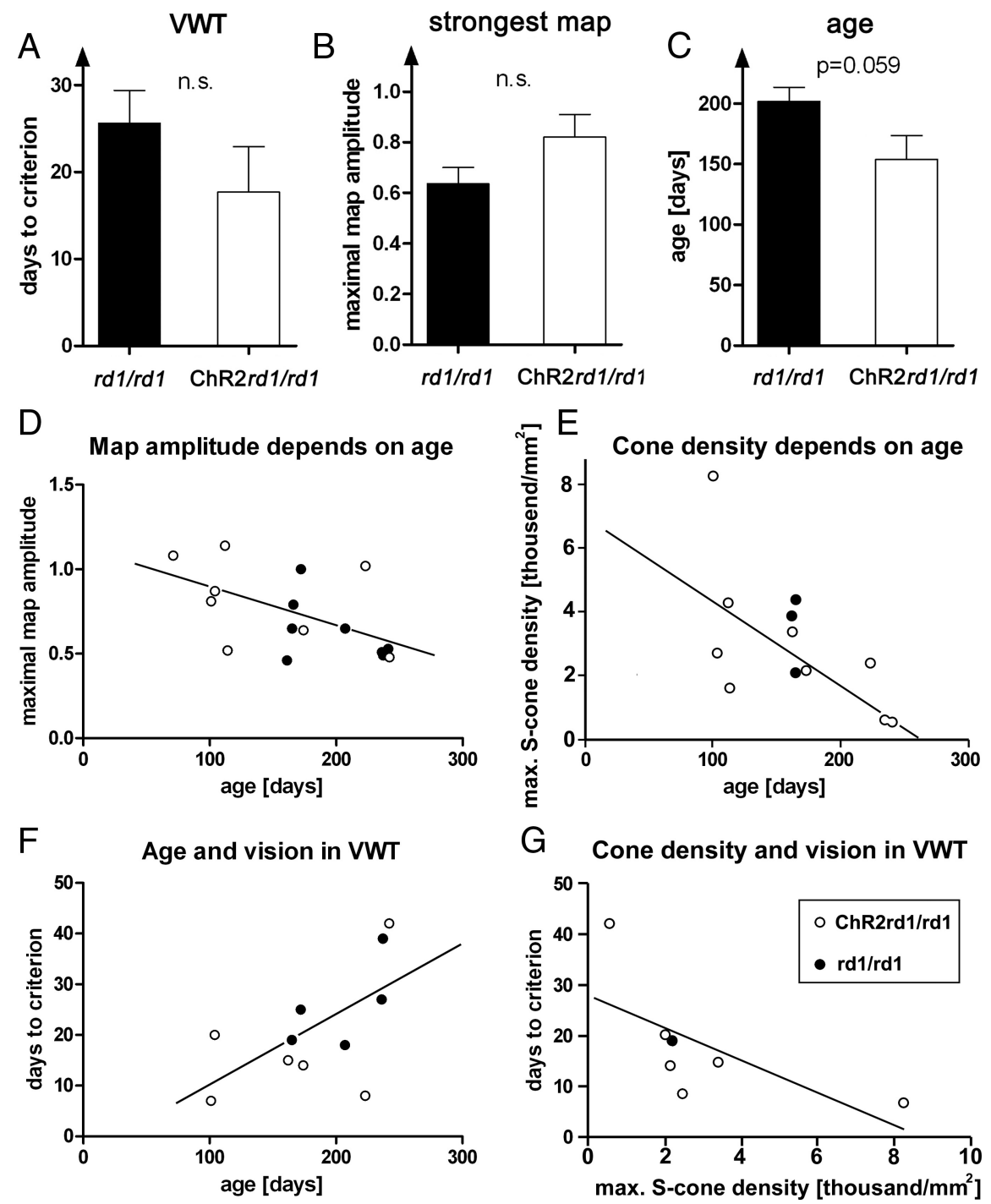

Figure 11. Summary diagrams comparing the visual performance of $r d 1 / r d 1$ and ChR2 $r d 1 / r d 1$ mice. $A$, Discrimination of light and dark fields in the VWT. A total of $9 \mathrm{rd} 1 / \mathrm{rd} 1$ mice and $10 \mathrm{ChR2} \mathrm{rd} 1 / \mathrm{rd} 1$ mice were tested. 0 them, $5 \mathrm{rd} 1 / \mathrm{rd} 1 \mathrm{mice}$ and 6 ChR2rd1/rd1 mice reached the 70\% criterion. The average time to reach the criterion and the SD are shown in the bar diagram. $B$, Strongest map of the cortical response after visual stimulation, expressed as fractional change in reflectance $\times 10^{4}$. Average of $8 \mathrm{rd} 1 / \mathrm{rd} 1$ and $8 \mathrm{ChR} 2 \mathrm{rd} 1 / \mathrm{rd} 1$ mice. C, Average age of the mice $(9 \mathrm{rd} 1 / \mathrm{rd} 1 \mathrm{mice}, 10 \mathrm{ChR} 2 \mathrm{rd} 1 / \mathrm{rd} 1 \mathrm{mice})$ at the optical imaging experiment. $\boldsymbol{D}$, Scatter diagram comparing the age of the mice and the maximum map amplitude. The line shows a linear regression fitted to the data. $\boldsymbol{E}$, Scatter diagram comparing the maximum S-cone density in the peripheral ventral retina and the age of the animals. There is considerable variation of the cone density for the different age groups. The linear regression line indicates that the residual cone density decreases with animal age. $\boldsymbol{F}$, Scatter diagram comparing visual performance, i.e., the training days needed to reach the $70 \%$ criterion in the VWT and the age of the animals. The line shows a linear regression. $G, S c a t t e r$ diagram comparing the residual S-cone density and the days to reach the $70 \%$ criterion in the VWT.

Another strategy to improve the sensitivity of light activated channels would be the coupling of the retinal-based light sensor with a biochemical amplification cascade. Lin et al. (2008) have used melanopsin, which normally is expressed in intrinsically photosensitive ganglion cells (Berson, 2003) to restore visual function in retinal degeneration mice by ectopic expression in a large number of ganglion cells. The newly melanopsin-expressing ganglion cells restored some visual functions such as discrimination of a light stimulus from a dark stimulus. The sensitivity of the newly melanopsin-expressing ganglion cells was comparable to the intrinsically photosensitive ganglion cells, which have a threshold of $\sim 5 \cdot 10^{11}$ photons $/ \mathrm{cm}^{2} / \mathrm{s}$ in the rat retina (Berson et al., 2002). This is sufficient to generate light responses under 
normal daylight conditions (Lin et al., 2008). However, responses mediated by melanopsin are sluggish: the response at light on is delayed and the response can last for many seconds after the visual stimulus is turned off.

\section{References}

Arenkiel BR, Peca J, Davison IG, Feliciano C, Deisseroth K, Augustine GJ, Ehlers MD, Feng G (2007) In vivo light-induced activation of neural circuitry in transgenic mice expressing channelrhodopsin-2. Neuron 54:205-218.

Berndt A, Yizhar O, Gunaydin LA, Hegemann P, Deisseroth K (2009) Bistable neural state switches. Nat Neurosci 12:229-234.

Berson DM (2003) Strange vision: ganglion cells as circadian photoreceptors. Trends Neurosci 26:314-320.

Berson DM, Dunn FA, Takao M (2002) Phototransduction by retinal ganglion cells that set the circadian clock. Science 295:1070-1073.

Bi A, Cui J, Ma YP, Olshevskaya E, Pu M, Dizhoor AM, Pan ZH (2006) Extopic expression of a microbial-type rhodopsin restores visual responses in mice with photoreceptor degeneration. Neuron 50:23-33.

Blanks JC, Adinolfi AM, Lolley RN (1974) Photoreceptor degeneration and synaptogenesis in retinal-degenerative (rd) mice. J Comp Neurol 156: 95-106.

Bowes C, Li T, Danciger M, Baxter LC, Applebury ML, Farber DB (1990) Retinal degeneration in the rd mouse is caused by a defect in the beta subunit of rod cGMP-phosphodiesterase. Nature 347:677-680.

Boyden ES, Zhang F, Bamberg E, Nagel G, Deisseroth K (2005) Millisecondtimescale, genetically targeted optical control of neural activity. Nat Neurosci 8:1263-1268.

Cang J, Kalatsky VA, Löwel S, Stryker MP (2005) Optical imaging of the intrinsic signal as a measure of cortical plasticity in the mouse. Vis Neurosci 22:685-691.

Carter-Dawson LD, LaVail MM, Sidman RL (1978) Differential effect of the rd mutation on rods and cones in the mouse retina. Invest Ophthalmol Vis Sci 17:489-498.

Claes E, Seeliger M, Michalakis S, Biel M, Humphries P, Haverkamp S (2004) Morphological characterization of the retina of the $\mathrm{CNGA3}\left({ }^{-1-}\right)$ $\mathrm{Rho}\left({ }^{-1}\right)$ mutant mouse lacking functional cones and rods. Invest Ophthalmol Vis Sci 45:2039-2048.

Derra G, Moench H, Fischer E, Giese H, Hechtfischer U, Heusler G, Koerber A, Niemann U, Noertemann F-C, Pekarski P, Pollmann-Retsch J, Ritz A, Weichmann U (2005) UHP lamp systems for projection applications. J Phys D Appl Phys 38:2995-3010.

Douglas RM, Alam NM, Silver BD, McGill TJ, Tschetter WW, Prusky GT (2005) Independent visual threshold measurements in the two eyes of freely moving rats and mice using a virtual-reality optokinetic system. Vis Neurosci 22:677-684.

Dräger UC, Hubel DH (1978) Studies of visual function and its decay in mice with hereditary retinal degeneration. J Comp Neurol 180:85-114.

Dräger UC, Olsen JF (1980) Origins of crossed and uncrossed retinal projections in pigmented and albino mice. J Comp Neurol 191:383-412.

Dräger UC, Olsen JF (1981) Ganglion cell distribution in the retina of the mouse. Invest Ophthalmol Vis Sci 20:285-293.

Farber DB, Flannery JG, Bowes-Rickman C (1994) The rd mouse story: seventy years of research on an animal model of inherited retinal degeneration. Prog Retin Eye Res 13:31-64.

Foster RG, Hankins MW (2002) Non-rod, non-cone photoreception in the vertebrates. Prog Retin Eye Res 21:507-527.

Greenberg KP, Pham A, Werblin FS (2010) A side-by-side comparison of the next generation of optical neuromodulators of retinal activity. Invest Ophthalmol Vis Sci 51:E-Abstract 3467.

Hattar S, Liao HW, Takao M, Berson DM, Yau KW (2002) Melanopsincontaining retinal ganglion cells: Architecture, projections, and intrinsic photosensitivity. Science 295:1065-1070.

Herreros de Tejada P, Muñoz Tedó C, Costi C (1997) Behavioral estimates of absolute visual threshold in mice. Vision Res 37:2427-2432.

Hughes A, Wieniawa-Narkiewicz E (1980) A newly identified population of presumptive microneurones in the cat retinal ganglion cell layer. Nature 284:468-470.

Jeon CJ, Strettoi E, Masland RH (1998) The major cell populations of the mouse retina. J Neurosci 18:8936-8946.

Jones BW, Watt CB, Frederick JM, Baehr W, Chen CK, Levine EM, Milam
AH, Lavail MM, Marc RE (2003) Retinal remodeling triggered by photoreceptor degenerations. J Comp Neurol 464:1-16.

Kalatsky VA, Stryker MP (2003) New paradigm for optical imaging: temporally encoded maps of intrinsic signal. Neuron 38:529-545.

Lagali PS, Balya D, Awatramani GB, Münch TA, Kim DS, Busskamp V, Cepko CL, Roska B (2008) Light-activated channels targeted to ON bipolar cells restore visual function in retinal degeneration. Nat Neurosci 11: 667-675.

Lanyi JK (1986) Halorhodopsin: a light-driven chloride ion pump. Annu Rev Biophys Chem 15:11-28.

Lehmann K, Löwel S (2008) Age-dependent ocular dominance plasticity in adult mice. PloS ONE 3:e3120.

Lin B, Koizumi A, Tanaka N, Panda S, Masland RH (2008) Restoration of visual function in retinal degeneration mice by ectopic expression of melanopsin. Proc Natl Acad Sci U S A 105:16009-16014.

Lin B, Masland RH, Strettoi E (2009) Remodeling of cone photoreceptor cells after rod degeneration in rd mice. Exp Eye Res 88:589-599.

Liu BH, Li P, Sun YJ, Li YT, Zhang LI, Tao HW (2010) Intervening inhibition underlies simple-cell receptive field structure in visual cortex. Nat Neurosci 13:89-96.

Lucas RJ, Douglas RH, Foster RG (2001) Characterization of an ocular photopigment capable of driving pupillary constriction in mice. Nat Neurosci 4:621-626.

Lyubarsky AL, Falsini B, Pennesi ME, Valentini P, Pugh EN Jr (1999) UVand midwave-sensitive cone-driven retinal responses of the mouse: a possible phenotype for coexpression of cone photopigments. J Neurosci 19:442-455.

Marc RE, Jones BW, Watt CB, Strettoi E (2003) Neural remodeling in retinal degeneration. Prog Retin Eye Res 22:607-655.

Marc RE, Jones BW, Anderson JR, Kinard K, Marshak DW, Wilson JH, Wensel T, Lucas RJ (2007) Neural reprogramming in retinal degeneration. Invest Ophthalmol Vis Sci 48:3364-3371.

Margolis DJ, Detwiler PB (2007) Different mechanisms generate maintained activity in ON and OFF retinal ganglion cells. J Neurosci 27:5994-6005.

Margolis DJ, Newkirk G, Euler T, Detwiler PB (2008) Functional stability of retinal ganglion cells after degeneration-induced changes in synaptic input. J Neurosci 28:6526-6536.

Mazzoni F, Novelli E, Strettoi E (2008) Retinal ganglion cells survive and maintain normal dendritic morphology in a mouse model of inherited photoreceptor degeneration. J Neurosci 28:14282-14292.

McGovern BP, Berlinguer Palmini R, Grossman N, Neill M, Drakalis E, Degenaar PA (2010) Towards an optogenetic retinal cell prosthesis. Invest Ophthalmol Vis Sci 51:E-Abstract 3468.

Münch TA, da Silveira RA, Siegert S, Viney TJ, Awatramani GB, Roska B (2009) Approach sensitivity in the retina processed by a multifunctional neural circuit. Nat Neurosci 12:1308-1316.

Murphy GJ, Rieke F (2006) Network variability limits stimulus-evoked spike timing precision in retinal ganglion cells. Neuron 52:511-524.

Nagel G, Szellas T, Huhn W, Kateriya S, Adeishvili N, Berthold P, Ollig D, Hegemann P, Bamberg E (2003) Channelrhodopsin-2, a directly lightgated cation-selective membrane channel. Proc Natl Acad Sci U S A 100:13940-13945.

Pang JJ, Gao F, Wu SM (2003) Light-evoked excitatory and inhibitory synaptic inputs to ON and OFF $\alpha$ ganglion cells in the mouse retina. J Neurosci 23:6063-6073.

Peichl L, Ott H, Boycott BB (1987) Alpha ganglion cells in mammalian retinae. Proc R Soc Lond B Biol Sci 231:169-197.

Pérez De Sevilla Müller L, Shelley J, Weiler R (2007) Displaced amacrine cells of the mouse retina. J Comp Neurol 505:177-189.

Prusky GT, Douglas RM (2004) Characterization of mouse cortical spatial vision. Vision Res 44:3411-3418.

Prusky GT, West PW, Douglas RM (2000) Behavioral assessment of visual acuity in mice and rats. Vision Res 40:2201-2209.

Prusky GT, Alam NM, Beekman S, Douglas RM (2004) Rapid quantification of adult and developing mouse spatial vision using a virtual optomotor system. Invest Ophthalmol Vis Sci 45:4611-4616.

Punzo C, Kornacker K, Cepko CL (2009) Stimulation of the insulin/mTOR pathway delays cone death in a mouse model of retinitis pigmentosa. Nat Neurosci 12:44-52.

Remé CE, Grimm C, Hafezi F, Marti A, Wenzel A (1998) Apoptotic cell death in retinal degenerations. Prog Retin Eye Res 17:443-464. 
Roska B, Werblin F (2001) Vertical interactions across 10 parallel, stacked representations in the mammalian retina. Nature 410:583-587.

Schmucker C, Seeliger M, Humphries P, Biel M, Schaeffel F (2005) Grating acuity at different luminances in wild-type mice and in mice lacking rod or cone function. Invest Ophthalmol Vis Sci 46:398-407.

Simpson JI (1984) The accessory optic system. Annu Rev Neurosci 7:13-41.

Stasheff SF (2008) Emergence of sustained spontaneous hyperactivity and temporary preservation of OFF responses in ganglion cells of the retinal degeneration (rd1) mouse. J Neurophysiol 99:1408-1421.

Strettoi E, Porciatti V, Falsini B, Pignatelli V, Rossi C (2002) Morphological and functional abnormalities in the inner retina of the $\mathrm{rd} / \mathrm{rd}$ mouse. J Neurosci 22:5492-5504.

Strettoi E, Pignatelli V, Rossi C, Porciatti V, Falsini B (2003) Remodeling of second-order neurons in the retina of $\mathrm{rd} / \mathrm{rd}$ mutant mice. Vision Res 43:867-877.

Sun W, LiN, He S (2002) Large-scale morphological survey of mouse retinal ganglion cells. J Comp Neurol 451:115-126.

Taylor WR, Vaney DI (2002) Diverse synaptic mechanisms generate direction selectivity in the rabbit retina. J Neurosci 22:7712-7720.

Tomita H, Sugano E, Yawo H, Ishizuka T, Isago H, Narikawa S, Kügler S, Tamai M (2007) Restoration of visual response in aged dystrophic RCS rats using AAV-mediated channelopsin-2 gene transfer. Invest Ophthalmol Vis Sci 48:3821-3826.

Tomita H, Sugano E, Isago H, Hiroi T, Wang Z, Ohta E, Tamai M (2010)
Channelrhodopsin-2 gene transduced into retinal ganglion cells restores functional vision in genetically blind rats. Exp Eye Res 90:429-436.

van Alphen B, Winkelman BH, Frens MA (2009) Age- and sex-related differences in contrast sensitivity in C57B1/6 mice. Invest Ophthalmol Vis Sci 50:2451-2458.

van Wyk M, Taylor WR, Vaney DI (2006) Local edge detectors: a substrate for fine spatial vision at low temporal frequencies in rabbit retina. J Neurosci 26:13250-13263.

van Wyk M, Wässle H, Taylor WR (2009) Receptive field properties of ONand OFF-ganglion cells in the mouse retina. Vis Neurosci 26:297-308.

Völgyi B, Deans MR, Paul DL, Bloomfield SA (2004) Convergence and segregation of the multiple rod pathways in mammalian retina. J Neurosci 24:11182-11192.

Wässle H, Levick WR, Cleland BG (1975) The distribution of the alpha type of ganglion cells in the cat's retina. J Comp Neurol 159:419-438.

Wässle H, Chun MH, Müller F (1987) Amacrine cells in the ganglion-cell layer of the cat retina. J Comp Neurol 265:391-408.

Wässle H, Puller C, Müller F, Haverkamp S (2009) Cone contacts, mosaics, and territories of bipolar cells in the mouse retina. J Neurosci 29:106-117.

Zhang F, Wang LP, Brauner M, Liewald JF, Kay K, Watzke N, Wood PG, Bamberg E, Nagel G, Gottschalk A, Deisseroth K (2007) Multimodal fast optical interrogation of neural circuitry. Nature 446:633-639.

Zhang Y, Ivanova E, Bi A, Pan ZH (2009) Ectopic expression of multiple microbial rhodopsins restores $\mathrm{ON}$ and $\mathrm{OFF}$ light responses in retinas with photoreceptor degeneration. J Neurosci 29:9186-9196. 